\title{
Evaluation Of FWENC Process For Treatment Of MVST Sludges, Supernates, And Surrogates
}

February 2003

\author{
Prepared by: John W. Barton \\ Authors: $\quad$ John W. Barton, Ph. D. \\ Staff Engineer \\ Roger D. Spence, Ph. D. \\ Senior Staff Engineer
}




\title{
DOCUMENT AVAILABILITY
}

Reports produced after January 1, 1996, are generally available free via the U.S. Department of Energy (DOE) Information Bridge.

Web site http://www.osti.gov/bridge

Reports produced before January 1, 1996, may be purchased by members of the public from the following source.

\author{
National Technical Information Service \\ 5285 Port Royal Road \\ Springfield, VA 22161 \\ Telephone 703-605-6000 (1-800-553-6847) \\ TDD 703-487-4639 \\ Fax 703-605-6900 \\ E-mail info@ntis.fedworld.gov \\ Web site http://www.ntis.gov/support/ordernowabout.htm
}

Reports are available to DOE employees, DOE contractors, Energy Technology Data Exchange (ETDE) representatives, and International Nuclear Information System (INIS) representatives from the following source.

Office of Scientific and Technical Information

P.O. Box 62

Oak Ridge, TN 37831

Telephone 865-576-8401

Fax 865-576-5728

E-mail reports@adonis.osti.gov

Web site http://www.osti.gov/contact.html

This report was prepared as an account of work sponsored by an agency of the United States Government. Neither the United States government nor any agency thereof, nor any of their employees, makes any warranty, express or implied, or assumes any legal liability or responsibility for the accuracy, completeness, or usefulness of any information, apparatus, product, or process disclosed, or represents that its use would not infringe privately owned rights. Reference herein to any specific commercial product, process, or service by trade name, trademark, manufacturer, or otherwise, does not necessarily constitute or imply its endorsement, recommendation, or favoring by the United States Government or any agency thereof. The views and opinions of authors expressed herein do not necessarily state or reflect those of the United States Government or any agency thereof. 
ORNL/TM-2003/30

\title{
EVALUATION OF FWENC PROCESS FOR TREATMENT OF MVST SLUDGES, SUPERNATES, AND SURROGATES
}

\author{
John W. Barton \\ Roger D. Spence
}

Date Published: February 2003

Prepared by

OAK RIDGE NATIONAL LABORATORY

P.O. Box 2008

Oak Ridge, Tennessee 37831-6285

managed by

UT-Battelle, LLC

for the

U.S. DEPARTMENT OF ENERGY

under contract DE-AC05-00OR22725 



\section{CONTENTS}

Page

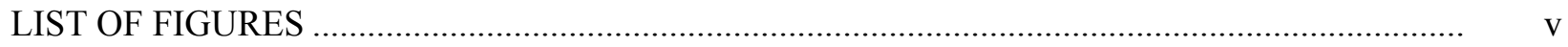

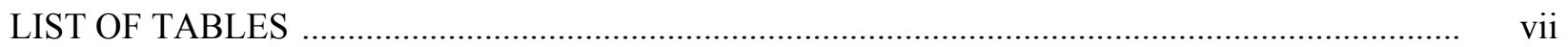

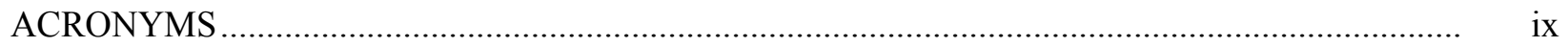

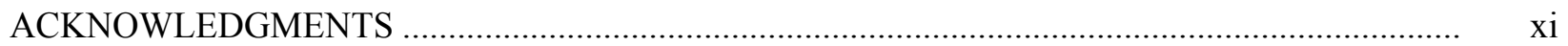

EXECUTIVE SUMMARY .............................................................................................

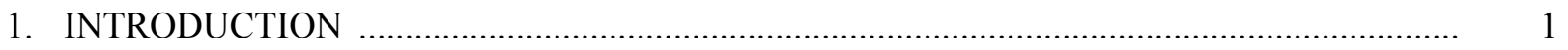

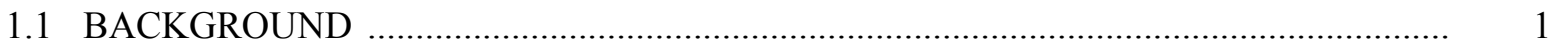

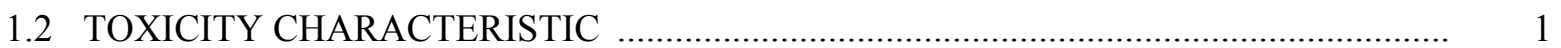

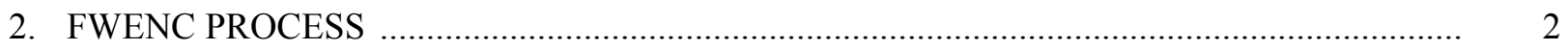

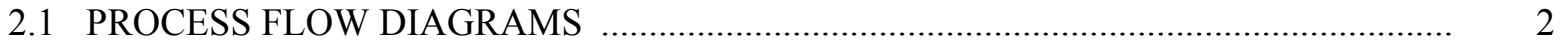

2.2 LABORATORY PROCEDURE EMULATING FWENC PROCESS ............................ 2

2.2.1 Process (Continued) For Decanted Wash/Rinse ................................................... 2

2.2.2 Process (Continued) For Settled Solids (Rinsed Sludge) Fraction ............................ 3

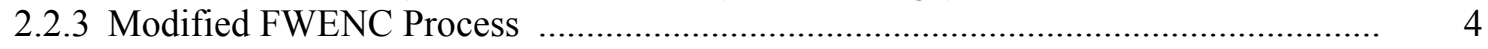

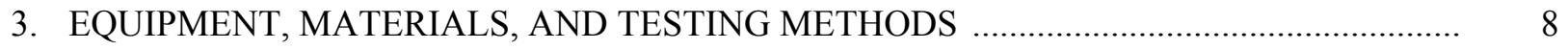

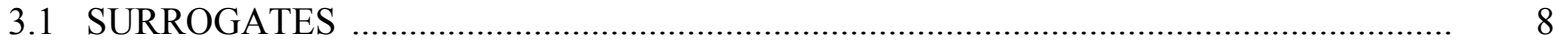

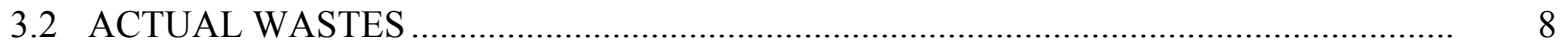

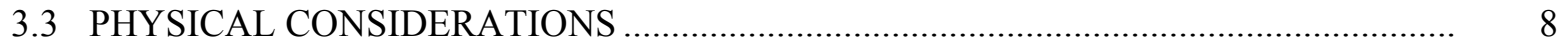

3.4 INITIAL SAMPLE COLLECTION AND CHARACTERIZATION …............................ 9

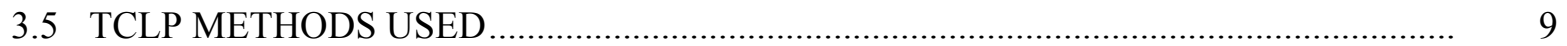

3.6 TCLP AND FREE WATER TESTING AT DESIGNATED INTERVALS ....................... 9

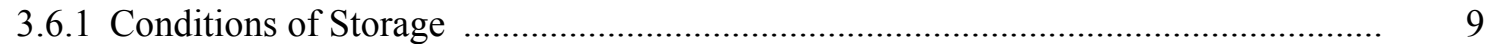

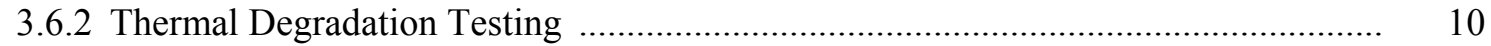

4. RESULTS FROM TESTING OF SURROGATE WASTES ............................................. 16

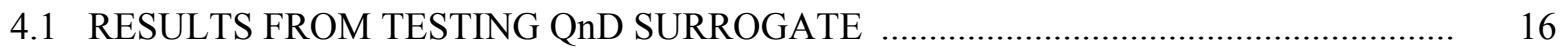

4.1.1 Results From Testing of 'Wet' Surrogate ............................................................... 16

4.1.2 Results from 'Optimum’ Treatment of QnD Surrogate .......................................... 16

4.1.3 Results from 'Alternate' Treatment of QnD Surrogate ........................................... 16

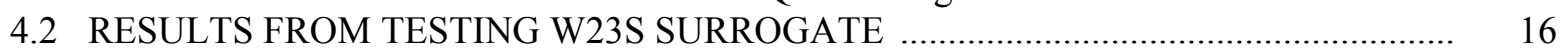

4.2.1 Results From Testing of 'Wet' Surrogate ............................................................ 16

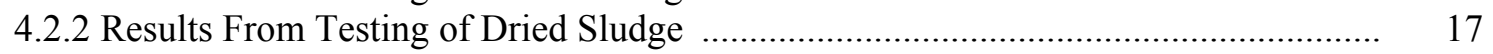

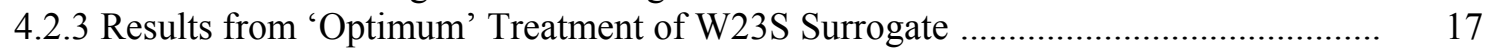

4.2.4 Results from 'Alternate' Treatment of W23S Surrogate .......................................... 17

4.2.5 Results from 'Modified Optimum' and 'Modified Alternate' Treatment of W23S

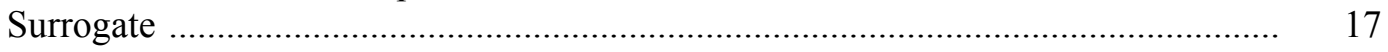

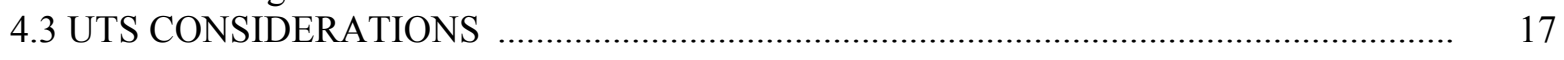


5. RESULTS FROM TESTING OF ACTUAL TANK WASTES …............................................

5.1 RESULTS FROM TESTING OF W23 ACTUAL TANK WASTE ................................. 25

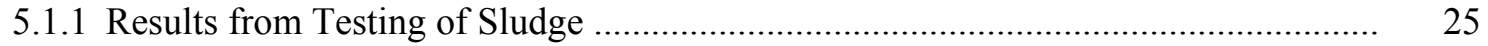

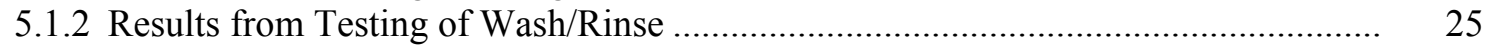

5.2 RESULTS FROM TESTING OF MVST ACTUAL TANK WASTE SLUDGE .............. 25

5.2.1 Simple Drying of W24, W25, and W28 sludges .................................................. 25

5.2.2 Application of 'Optimum' Treatment to W26 and W27 Sludges ............................. 25

5.3 RESULTS FROM TESTING OF MVST ACTUAL TANK WASTE WASH/RINSE ....... $\quad 26$

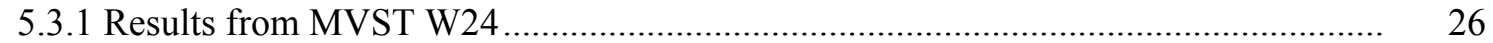

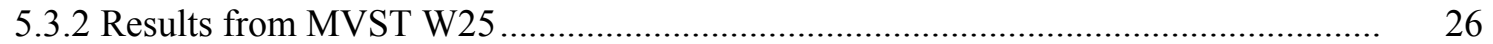

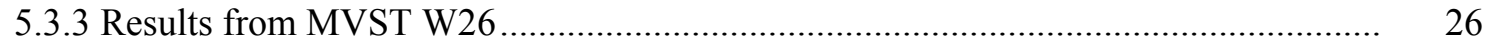

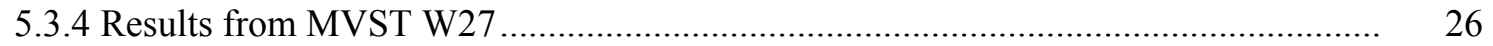

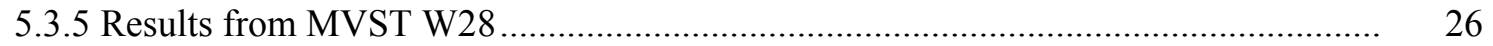

5.3.6 Results from MVST W31 ........................................................................................... 26

5.4 FWENC BASIS FOR NOT ADDING STABLIZING AGENTS TO THE WASH/RINSE 27

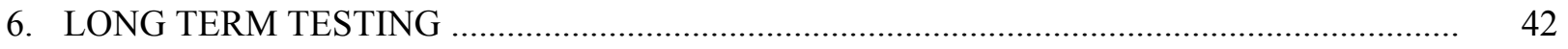

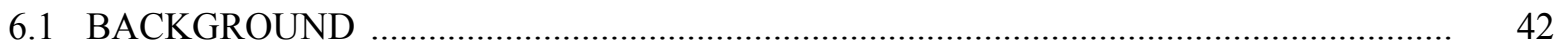

6.2 FREE WATER TEST RESULTS AFTER NINE MONTHS …...................................... 42

6.3 THERMAL DEGRADATION TESTING ...................................................................... 42

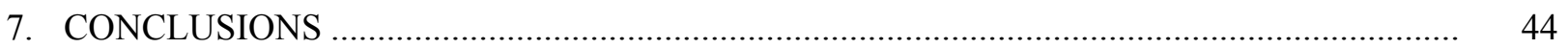

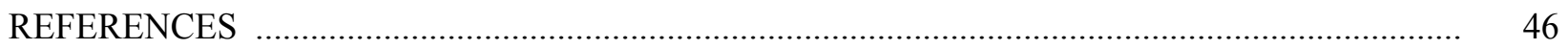




\section{LIST OF FIGURES}

$\begin{array}{ll}\text { Figure } & \text { Page }\end{array}$

2.1 Flowchart of FWENC treatment process for washed sludge ........................................ 5

2.2 Flowchart of FWENC treatment process for wash/rinse ................................................ 6

2.3 Flowchart of chemical additive processing for the FWENC process...................................

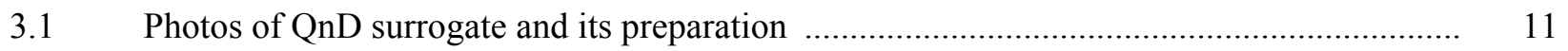

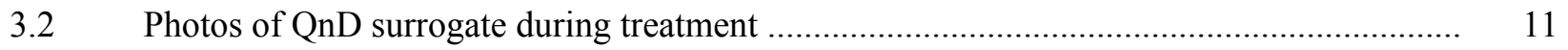

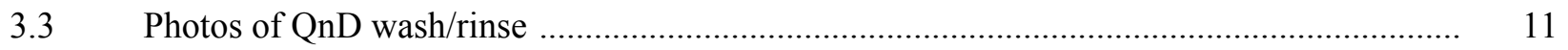

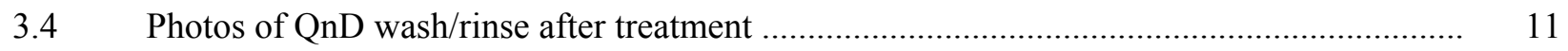

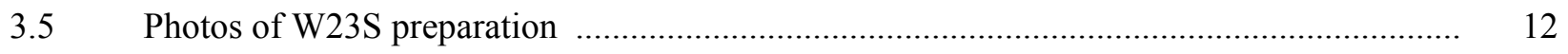

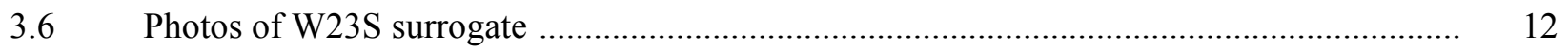

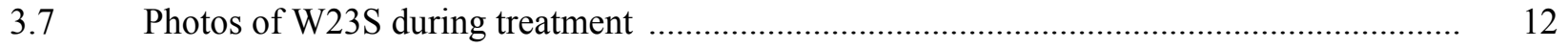

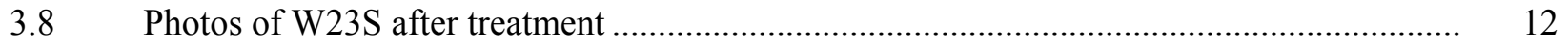

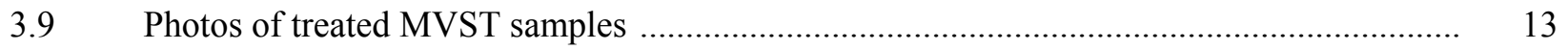

3.10 Photos of dried MVST samples (close up) without chemical additives ............................. 13

3.11 Photos of dried MVST samples subjected to 'Optimum' treatment …................................ 13

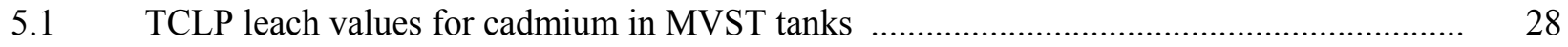

5.2 TCLP leach values for chromium in MVST tanks ....................................................... 29

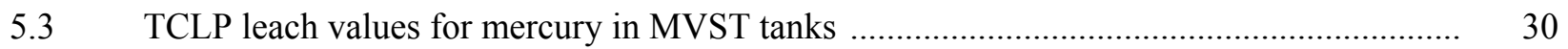

5.4 Distribution of cadmium between solid and liquid for TCLP extractions and sludge rinsing

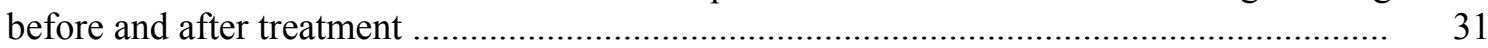

5.5 Distribution of chromium between solid and liquid for TCLP extractions and sludge rinsing before and after treatment

5.6 Distribution of mercury between solid and liquid for TCLP extractions and sludge rinsing before and after treatment 


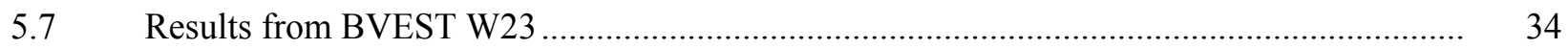

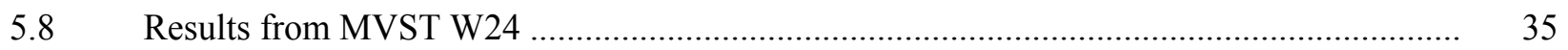

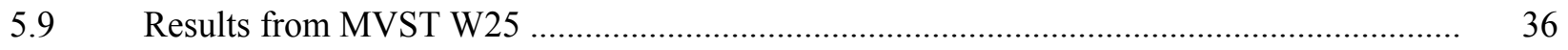

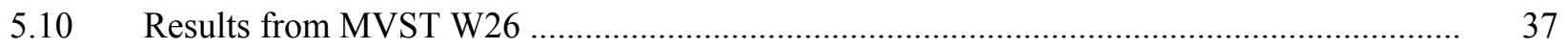

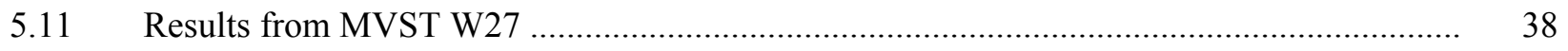

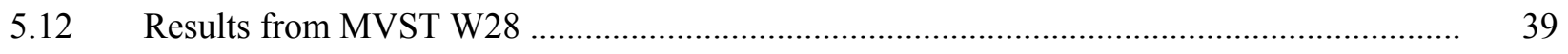

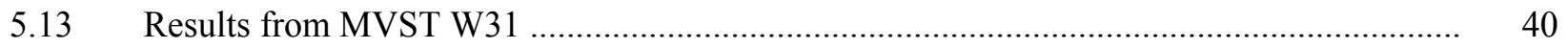

6.1 Photo of unconditioned trailer used to store treated samples of W23S for 9 months ........... 42

6.2 Photo of thermal cycler and humidity-controlled containers containing treated W23S ........ 43 


\section{LIST OF TABLES}

Table

Page

0.1 RCRA pass/failures using TCLP protocol of tank sludge surrogates after treatment .......... xiv

0.2 RCRA pass/failures using TCLP protocol of the actual sludge samples after treatment ....... xiv

3.1 'Quick and Dirty' surrogate characterization and comparison ...................................... 14

3.2 Representative surrogate characterization and comparison............................................ 15

4.1 TCLP concentrations of metals and radionuclides for 'Quick and Dirty' surrogate wet sludge

4.2 Calculated TCLP concentrations of metals and radionuclides for Quick and Dirty surrogate wash/rinse

4.3 TCLP leach concentrations of metals and radionuclides for QnD stabilized sludge surrogate-'Optimum' treatment

4.4 TCLP leach concentrations of metals and radionuclides for QnD stabilized wash/rinse-

'Optimum' treatment

4.5 TCLP concentrations of metals and radionuclides for QnD stabilized surrogate- 'Alternate'

treatment

4.6 TCLP concentrations of metals and radionuclides for QnD stabilized wash/rinse-

'Alternate' treatment

4.7 TCLP concentrations of metals and radionuclides for W23S surrogate wet sludge (averages of triplicate TCLP).

4.8 Theoretical leach TCLP concentrations of metals and radionuclides for W23S surrogate wash/rinse...

4.9 TCLP concentrations of metals and radionuclides for W23S surrogate dry sludgeuntreated

4.10 TCLP concentrations of metals and radionuclides for W23S stabilized surrogate'Optimum' treatment...

4.11 TCLP concentrations of metals and radionuclides for W23S stabilized wash/rinse'Optimum' treatment...

4.12 TCLP concentrations of metals and radionuclides for W23S stabilized surrogate'Alternate' treatment 
4.13 TCLP concentrations of metals and radionuclides for W23S stabilized wash/rinse-

'Alternate' treatment

4.14 Matrix of surrogate results

4.15 Comparison of RCRA versus UTS criteria

4.16 TCLP pass/failures of the various surrogate components after specific treatments based on UTS specifications

5.1 Matrix of MVST tanks and pass/fail results from a wet TCLP of the sludge (after wash) and the wash/rinse.

5.2 Pass/fail estimates based on 1996 measurements (Bayne et al., 1997) of MVST supernatants

5.3 Pass/fail estimates based on 2000 measurements of MVST sludges 


\section{ACRONYMS}

BVEST Bethel Valley Evaporator Storage Tanks

CFR Code of Federal Regulations

DOE Department of Energy

EM Environmental Management

EPA Environmental Protection Agency

FWENC Foster Wheeler Environmental Corporation

FY Fiscal Year

HQ Headquarters

LAW Low Activity Waste

LOD Loss On Drying

LDR Land Disposal Restrictions

LGWO Liquid and Gaseous Waste Operations

MVST Melton Valley Storage Tanks

ND Non-Detect

NRC Nuclear Regulatory Commission

NTS Nevada Test Site

OR Oak Ridge

ORNL Oak Ridge National Laboratory

ORO Oak Ridge Operations

ORR Oak Ridge Reservation

ppm parts per million (for TCLP extract concentrations $\mathrm{mg} / \mathrm{L}$ )

QnD Quick and Dirty surrogate

RCRA Resource Conservation and Recovery Act

TC Toxicity Characteristic

TCLP Toxicity Characteristic Leach Procedure

TFA Tanks Focus Area

TIC Total Inorganic Carbon

TOC Total Organic Carbon

TS Total Solids

TTP Technical Task Plan

UTS Universal Treatment Standards

W23S W23 Surrogate (representative of the W23 sludge sample)

WIPP Waste Isolation Pilot Plant 



\section{ACKNOWLEDGMENTS}

Successful completion of this project was made possible through a dedicated team effort involving many individuals and organizations over the span of two years. The U.S. Department of Energy (DOE) Tanks Focus Area (TFA) was the major provider of funding for the project and made possible the integration of technical support between different organizations at the Oak Ridge Reservation. The TFA recognized that support of this project would benefit environmental management activities at Oak Ridge, specifically closure of the MVST tanks, and across the DOE complex by evaluating the performance of proposed sludge stabilization technologies.

Program contributions of J. N. Dial and D. D. Green, of DOE-Oak Ridge Operations (DOE-ORO), were vital to the project. S. M. Robinson of the ORNL Nuclear Sciences and Technology Division, Christine Langton of the Savannah River Technology Center (SRTC), SC, Bill Holtscheiter of SRTC, and John Harbour of SRTC have provided dedicated support through their coordination of the project between TFA, DOE-ORO, and Waste Operations.

The authors wish to express appreciation to the following staff members of the ORNL Chemical and Analytical Sciences Division who made important contributions to this work: J. M. Keller, J. M. Giaquinto, and D. L. Denton. C. M. Mattus of Nuclear Sciences and Technology Division provided invaluable technical assistance. P. A. Taylor and S. M. Robinson of Nuclear Sciences and Technology Division, as well as K. T. Klasson of Life Sciences Division, provided very helpful review comments. 



\section{EXECUTIVE SUMMARY}

In 1998, the Foster Wheeler Environmental Corporation (FWENC) was awarded an 11-year contract to treat transuranic waste at the Oak Ridge National Laboratory, including Melton Valley Storage Tank (MVST) waste. Their baseline tank waste process consists of:

(1) Separating the supernate from the sludge,

(2) Washing the sludge with water and adding this wash water to the supernate,

(3) Stabilizing the supernate/wash water or the washed sludge with additives if either are projected to fail Resource Conservation Recovery Act (RCRA) Toxic Characteristics Leaching Protocol (TCLP) criteria, and

(4) Stabilizing both the washed sludge and supernate/wash water by vacuum evaporation.

An 'Optimum' treatment procedure consisted of adding a specified quantity of two stabilizers - ThioRed ${ }^{\circledR}$ and ET Soil Polymer ${ }^{\circledR}$ — and an 'Alternate' treatment simply increased the amount of ThioRed ${ }^{\circledR}$ added.

This report presents the results of a study funded by the Tanks Focus Area (TFA) to provide Oak Ridge Operations (ORO) with independent laboratory data on the performance of the baseline process for treating the sludges, including washing the sludge and treating the wash water (although supernates were not included in the wash water tests). Two surrogate and seven actual tank wastes were used in this evaluation. Surrogate work, as well as the initial work with actual tank sludge, was based on an existing sludge sample from Bethel Valley Evaporator Storage Tank (BVEST) W23. One surrogate was required to be based on a surrogate previously developed to mimic the weighted average chemical composition of the MVST-BVEST using a simple mix of reagent grade chemicals and water, called the "Quick and Dirty" surrogate (QnD). The composition of this surrogate was adjusted toward the measured composition of W23 samples. The other surrogate was prepared to be more representative of the W23 sludge sample by precipitation of a nitrate solution at high $\mathrm{pH}$, separating the solution from the solids, measuring the composition of the wet solids, and adding reagent grade chemicals to closely mimic the measured composition of the W23 sample.

Without any treatment, both surrogates failed TCLP limits for mercury, chromium, and lead. Using the 'Optimum' treatment provided by FWENC, both rinsed tank sludge surrogates were stabilized and passed TCLP limits. The wash/rinse from the simple surrogate of reagent grade chemicals and water passed TCLP after 'Optimum' treatment. However, the wash/rinse from the more representative surrogate gave mixed results; failing TCLP for mercury after both an 'Optimum' and an 'Alternate' treatment in the first triplicate set, but passing after either treatment in a repeat triplicate set. Both surrogates (sludge and wash/rinse) failed to pass Universal Treatment Standard (UTS) limits after both 'Optimum' and 'Alternate' treatments, implying that these treatments will not be satisfactory if the sludge is declared hazardous waste per RCRA. The surrogate results are summarized in the table below.

During the course of this study, sludge samples were taken from six tanks: W24, W25, W26, W27, W28, and W31. These samples were characterized and then made available for the treatment studies of this project. Sludge samples from Bethel Valley Evaporator Storage Tank (BVEST) W23 and the MVST tank farm were analyzed and subjected to the FWENC 'Optimum' stabilization process. Three sludge samples from MVST that could pass a TCLP test after being washed with water also passed after drying without stabilizer addition. These three washed, dried tank sludge samples could also now meet UTS criteria (the 
Table 0.1 RCRA pass/failures using TCLP protocol of tank surrogates after treatment

\begin{tabular}{lllll}
\hline \multicolumn{1}{c}{ Surrogate type } & After washing & $\begin{array}{c}\text { Dried waste form } \\
\text { (no additives) }\end{array}$ & $\begin{array}{c}\text { Optimum } \\
\text { treatment }\end{array}$ & $\begin{array}{c}\text { Alternate } \\
\text { treatment }\end{array}$ \\
\hline QnD sludge & Fail & Not tested & Pass & Pass \\
QnD wash/rinse & Fail & Not tested & Pass & Pass \\
W23S sludge & Fail & Fail & Pass & Pass \\
W23S wash/rinse & Fail & Not tested & 1. Fail & 1. Fail \\
& & & 2. Pass & 2. Pass \\
\hline
\end{tabular}

washed sludge had previously failed UTS). MVST samples from W26 and W27 failed TCLP RCRA characteristic and UTS criteria for mercury both before and after treatment. W26 and W27 sludges were not subjected to the 'Alternate' stabilization process proposed by FWENC. W23 sludge passed both criteria after 'Optimum' treatment. All TCLP/stabilization tests on sludges were performed in triplicate to ensure accuracy. The FWENC 'Modified Optimum' treatment process failed to stabilize mercury in the wash/rinses from W26, W27, and W28 MVST sludges. A simple drying process (without chemical stabilizer addition) was applied to the rinses from W24 and W25 MVST tank sludges per the FWENC process; both wash/rinses failed in cadmium, while W25 additionally failed in chromium. The proposed treatment did not consistently make the treated tank sludge or its surrogate non-hazardous by RCRA TCLP definition. The following table summarizes these results with the actual tank sludge samples.

Table 0.2. RCRA pass/failures using TCLP protocol of the actual sludge samples after treatment

\begin{tabular}{rlllll}
\hline \multirow{2}{*}{$\begin{array}{c}\text { MVST } \\
\text { tank }\end{array}$} & \multicolumn{2}{c}{ After washing } & & \multicolumn{2}{c}{ After drying } \\
\cline { 2 - 3 } \cline { 5 - 6 } W-23 & Sludge & Wash/rinse & & Sludge & Wash/rinse \\
W-24 & Pass & Pass & & Pass & Pass \\
W-25 & Fail & Fail & & Pass & Fail \\
W-26 & Fail & Fail & & Pass & Fail \\
W-27 & Fail & Fail & & Fail & Fail \\
W-28 & Pass & Fail & & Fail & Fail \\
W-31 & Fail & Fail & & Pass & Fail \\
& & Fail & & Not tested & Not tested \\
\hline
\end{tabular}

Some dried liquid and some dried sludge samples were still hazardous by TCLP after treatment, indicating a significant risk of not meeting performance criteria for portions of the MVST sludge during a field treatment using the proposed process. The TCLP failures for cadmium in the treated liquid, resulted from the process incorrectly predicting that no stabilizer addition was required. Modifying the calculation procedure may prevent future failures for a given sample, but these failures highlighted the risks involved in using grab samples to determine whether to add the stabilizer. Modest discrepancies in sample characterization made the difference between passing and failing. Surrogate work indicated that lack of stabilizer was not a contributing cause to failure, so adding more stabilizer (as prescribed by the FWENC 'Alternate' process) will not result in a passing TCLP performance. Surrogate work also indicated the treated waste will not accumulate free water or become hazardous as a result of being stored under local conditions. 


\section{INTRODUCTION}

\subsection{BACKGROUND}

Oak Ridge and Idaho have hundreds of thousands of gallons of low-level mixed waste in underground storage tanks that are to be treated for disposal. Tanks Focus Area (TFA) funded this work to (1) address the Oak Ridge concern for stabilization of hazardous components within their immobilized waste forms, (2) contribute to the Idaho low activity waste (LAW) issue, and (3) perform an independent laboratory test of the Foster Wheeler Environmental Corporation (FWENC) process for immobilization of Oak Ridge waste. Oak Ridge National Laboratory (ORNL) conducted both immediate and longer-term leach testing to give confidence that the final waste forms will retain hazardous metals and meet Resource Conservation and Recovery Act (RCRA) Land Disposal Restriction (LDR) limits. Since storage on site may occur prior to shipment to the Waste Isolation Pilot Plant (WIPP) or the Nevada Test Site (NTS), it was important to confirm that the waste form remains stable over time and will meet TCLP LDR limits at the time of shipment. ORNL initiated long term testing of both simulated and actual waste streams in FY 2000 and completed initial processing of surrogates and several actual wastes in FY 2001 using the FWENCproposed process.

This report presents results (from the project's start at the beginning of FY 2000 to the end of FY 2001) from stabilization studies of two different surrogate tank wastes and seven actual MVST waste samples. The stabilization process used was developed by FWENC and combines techniques of sluicing, dehydration, and stabilizer addition to achieve a final solid waste product that should no longer display the characteristic of toxicity as outlined in 40 CFR 261.24.

\subsection{TOXICITY CHARACTERISTIC}

Toxicity characteristics of a waste are measured as the potential for the toxic constituents in the waste to leach out and contaminate groundwater at levels of concern to human health and the environment. To determine if a waste exhibits the toxicity characteristic, constituents are extracted in a procedure that simulates leaching action in municipal landfills (Toxic Characteristic Leaching Procedure [TCLP], Environmental Protection Agency (EPA) Test Method 1311). Details regarding the Toxicity Characteristic as defined by EPA, as well as the TCLP EPA test procedure can be found at http://www.epa.gov/ 


\section{FWENC PROCEDURE}

\subsection{FLOW DIAGRAMS}

The FWENC process is diagrammed in Fig. 2.1, Fig. 2.2, and Fig. 2.3. Tank surrogates and actual wastes were first washed with 5 parts water to 1 part wet sludge and allowed to settle. This generated two fractions, referred to as 'sludge' (settled solids) and 'wash/rinse' (decanted liquid) in this report. Samples from each fraction were tested to determine whether the fraction displayed the toxicity characteristic in its final dehydrated form. If either fraction failed to pass, then samples from that fraction were treated using an 'Optimum' formulation of chemical additives, and then retested for toxicity characteristics. If this treatment failed, an 'Alternate' formulation was used to treat another set of samples, followed by TCLP testing. In FY 2001, after initial results from this report were available, FWENC redesigned the 'Optimum' process for tank supernates; previously, the process had called for chemical addition after evaporation - the 'Modified Optimum' process called for chemical treatment prior to evaporation steps.

\subsection{LABORATORY PROCEDURE EMULATING FWENC PROCESS}

A laboratory procedure based on the process description provided by FWENC was written to simulate the FWENC process as follows:

1. One mass of raw form surrogate or sludge is mixed with 3.8 masses of process water for 30 minutes aggressively. Alternatively, one part sludge/surrogate may be mixed with 5 parts process water.

2. The mixture is allowed to settle for at least 12 hours and any qualitative observations are recorded.

3. The top layer above the apparent solids level is decanted to within practical limits--some wash/rinse liquid may remain with solids.

4. The mass of each "phase" is measured- the decanted wash/rinse and settled solids fractions - and compared to the initial mass (starting mass of surrogate sludge and process water).

5. Each phase is covered or sealed while not in use to retard evaporative losses before further processing.

\subsubsection{Process (Continued) For Decanted Wash/Rinse}

6. Loss on drying (LOD) is measured at $110^{\circ} \mathrm{C}$ using a small sub-sample of the decanted wash/rinse.

7. Total concentration of $\mathrm{Hg}, \mathrm{Pb}, \mathrm{Cd}$, and $\mathrm{Cr}$ (the only RCRA metals included in the surrogate and the only potential failures in the MVST tank sludges) in the rinse is measured. In most cases, process metals were also measured, although this was not required by the FWENC process.

8. The target mass range to concentrate all of the decanted wash/rinse to approximately $45-50 \%$ TS (total solids) using vacuum evaporation $\left(\sim 20\right.$ " $\mathrm{Hg}$ at $\left.80^{\circ} \mathrm{C}\right)$ is calculated. If the mass falls below the target range, but the sample still contains a liquid layer and the mass is within "reasonable" range of the target range, water is added to bring the sample back within the desired mass range. If the sample has dried (no liquid), then the dried sample is re-dissolved and re-evaporated to the correct mass. In general, the wash/rinse should not be concentrated overnight, or unattended, to decrease the chances of overevaporating.

9. Based on characterization data, calculations are made to determine if the sample contains enough of the RCRA metals to theoretically fail TCLP, if dry. In this kind of calculation, a conservative assumption is made that the RCRA metals in this phase would dissolve and completely extract during TCLP after drying. Although a TCLP extraction can not be performed on a liquid sample, characterization data permit prediction of worst-case TCLP failure assuming an evaporative treatment.

10. Based on characterization data, the amount of concentrated wash/rinse needed to give enough solids for TCLP testing after processing is estimated. It is used as the baseline sample size for the remaining 
process steps. If this quantity exceeds the total amount of concentrated wash/rinse, then the entire quantity is processed.

11. If the theoretical calculation in Step 4 indicates no TCLP failure, the concentrated sample is dried to a constant weight under a partial vacuum $(\sim 20 \mathrm{Hg})$ at $80{ }^{\circ} \mathrm{C}$. TCLP performance of this dried sample is also measured. If it passes, processing of the wash/rinse is stopped and Steps 4 and 5 are repeated two more times (i.e., evaporate and test TCLP performance in triplicate) if there is enough concentrated wash/rinse. If the calculation indicates TCLP failure, or if drying without addition of chemical stabilizers results in TCLP failure, then the addition of stabilizers prior to drying is investigated (see following steps).

12. The sample size estimated in Step 5 is treated with ThioRed ${ }^{\circledR}$ ('Optimum' treatment)

a. $\quad$ ThioRed $^{\circledR}$ (a reddish liquid) is added at the level of $0.12 \mathrm{X}$, where $\mathrm{X}$ is the original concentrated sample mass

b. The treated sample is mixed for at least 15 minutes and allowed to react unmixed for at least one hour

c. ET Soil Polymer ${ }^{\circledR}$ is then added at $0.01 \mathrm{X}$, where $\mathrm{X}$ is the original concentrated sample mass

d. The treated sample is mixed for at least 15 minutes

e. The sample is then allowed to react unmixed for at least 6 hours

f. The sample is then dried under a partial vacuum $\left(\sim 20\right.$ "Hg) at $80{ }^{\circ} \mathrm{C}$ to a constant weight and TCLP performance is assayed. If the sample passes, then processing is stopped These steps are repeated two more times (i.e., conduct stabilization, drying, and TCLP in triplicate), quantity permitting.

13. If TCLP results from Step 7 above do not meet acceptance criteria, another sample will be treated with ThioRed $^{\circledR}$ ('Alternate' treatment)

g. ThioRed ${ }^{\circledR}$ is added at $0.20 \mathrm{X}$, where $\mathrm{X}$ is the original concentrated sample mass

$\mathrm{h}$. The sample is then mixed for at least 15 minutes and allowed to react unmixed for at least one hour

i. ET Soil Polymer ${ }^{\circledR}$ is added at $0.01 \mathrm{X}$, where $\mathrm{X}$ is the original concentrated sample mass

j. The sample is then mixed for at least 15 minutes

$\mathrm{k}$. It is then allowed to react unmixed for at least 6 hours

1. Finally, the sample is dried under a partial vacuum $(\sim 20 " \mathrm{Hg})$ at $80{ }^{\circ} \mathrm{C}$ to a constant weight. TCLP performance is then assayed. If the sample passes, then processing is halted at this point, and the test is repeated two more times (i.e., conduct stabilization, drying, and TCLP in triplicate), quantity permitting.

14. The step above - Step 6, 7, or 8 - which results in a blend that meets acceptance criteria will be used to process remaining wash/rinse material

15. If none of the treatment options meet the acceptance criteria, concentrated wash/rinse is stored until alternative treatment plans are made.

\subsubsection{Process (Continued) For Settled Solids (Rinsed Sludge) Fraction}

6. First, loss on drying (LOD) at $110^{\circ} \mathrm{C}$ of a small sub-sample of the settled solids fraction (the rinsed sludge) is measured and triplicate 'wet' TCLP tests are conducted on samples.

7. The amount of wet sludge required to give enough dried sludge for TCLP testing is calculated and used as the baseline sample size for the remaining process steps

8. If the wet sludge passes TCLP, samples of the sludge are then dried to a constant weight under a partial vacuum ( 20 " $\mathrm{Hg})$ at $80^{\circ} \mathrm{C}$ and TCLP performance is assayed. If the sample passes, processing of the sludge is stopped, and two additional TCLP assays are conducted for verification. The remainder of the sludge is then treated in a similar manner. If the dried sludge fails TCLP, wet or dry, then stabilizers are added prior to complete drying

9. Treat with ThioRed ${ }^{\circledR}$ ('Optimum' treatment)

a. $\quad \operatorname{ThioRed}^{\circledR}$ (a reddish liquid) is added at the level of $0.10 \mathrm{X}$, where $\mathrm{X}$ is the original concentrated sample mass

b. The treated sample is mixed for at least 15 minutes and allowed to react unmixed for at least one hour

c. ET Soil Polymer ${ }^{\circledR}$ is then added at $0.01 \mathrm{X}$, where $\mathrm{X}$ is the original concentrated sample mass 
d. The treated sample is mixed for at least 15 minutes

e. The sample is then allowed to react unmixed for at least 6 hours

f. The sample is then dried under a partial vacuum $\left(\sim 20\right.$ "Hg) at $80^{\circ} \mathrm{C}$ to a constant weight and TCLP performance is assayed. If the sample passes, then processing is stopped These steps are repeated two more times (i.e., conduct stabilization, drying, and TCLP in triplicate), quantity permitting.

10. If Step 4 does not result in a blend that meets acceptance criteria, then a separate sample will be treated with ThioRed ${ }^{\circledR}$ ('Alternate' treatment)

g. ThioRed ${ }^{\circledR}$ is added at $0.20 \mathrm{X}$, where $\mathrm{X}$ is the original concentrated sample mass

$\mathrm{h}$. The sample is then mixed for at least 15 minutes and allowed to react unmixed for at least one hour

i. ET Soil Polymer ${ }^{\circledR}$ is added at $0.01 \mathrm{X}$, where $\mathrm{X}$ is the original concentrated sample mass

j. The sample is then mixed for at least 15 minutes

$\mathrm{k}$. It is then allowed to react unmixed for at least 6 hours

1. Finally, the sample is dried under a partial vacuum $(\sim 20 " \mathrm{Hg})$ at $80{ }^{\circ} \mathrm{C}$ to a constant weight. TCLP performance is then assayed. If the sample passes, then processing is halted, and the test is repeated two more times (i.e., conduct stabilization, drying, and TCLP in triplicate), quantity permitting.

11. If Step 6 above results in a blend that meets acceptance criteria, then the remaining settled solids will be treated with the same method.

12. If none of the process steps - Steps 3, 4, or 5 - produces an acceptable blend, remaining settled solids will be stored until further treatment plans are made.

\subsubsection{Modified FWENC Process}

FWENC redesigned the 'Optimum' process for tank rinse/supernates after significant salt precipitation was noted during the first evaporation stage; previously, the process had called for chemical addition after the first stage. The 'Modified Optimum' process calls for chemical treatment prior to any evaporation, which might enable better contact between the stabilizer and heavy metals. The amount of chemical to be added doesn't change, but only one evaporation step (to complete dryness) is now required. 


\section{Detailed Sludge FWENC Treatment}

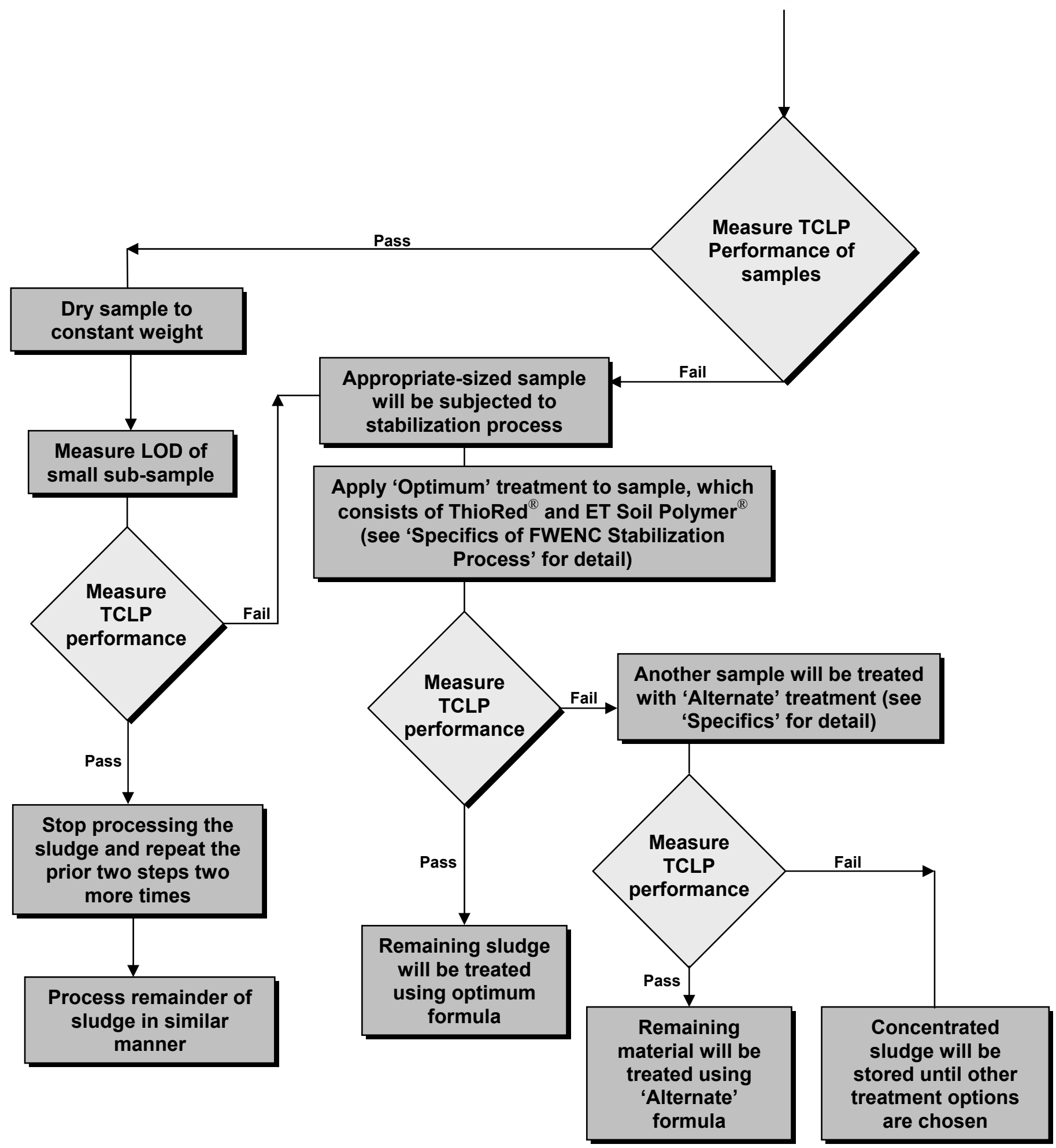

Fig 2.1. Flowchart of FWENC treatment process for washed sludge. 


\section{Detailed Wash/Rinse/Supernate FWENC Process}

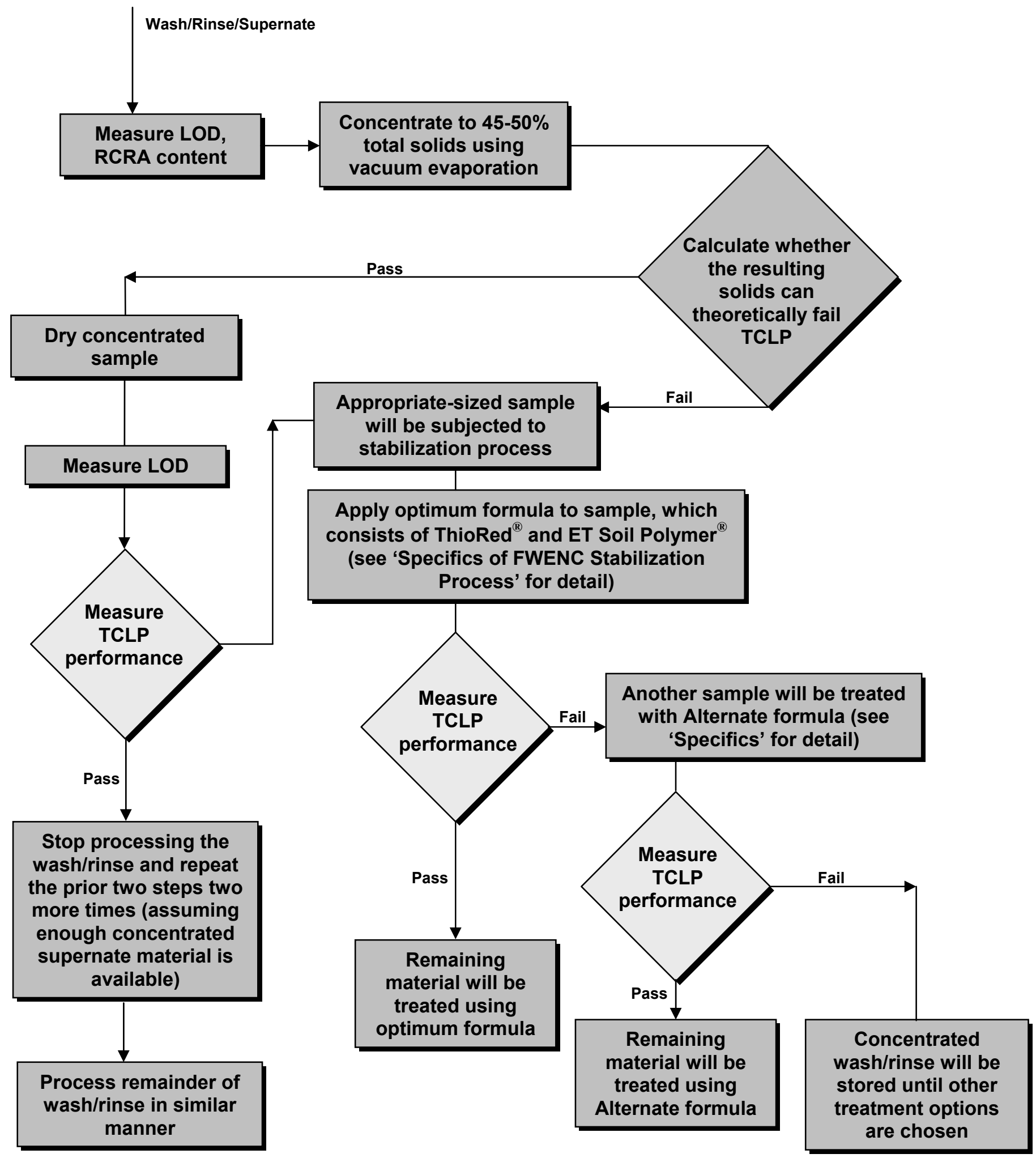

Fig 2.2. Flowchart of FWENC treatment process for wash/rinse. 


\section{SPECIFICS OF FWENC STABILZATION PROCESS}

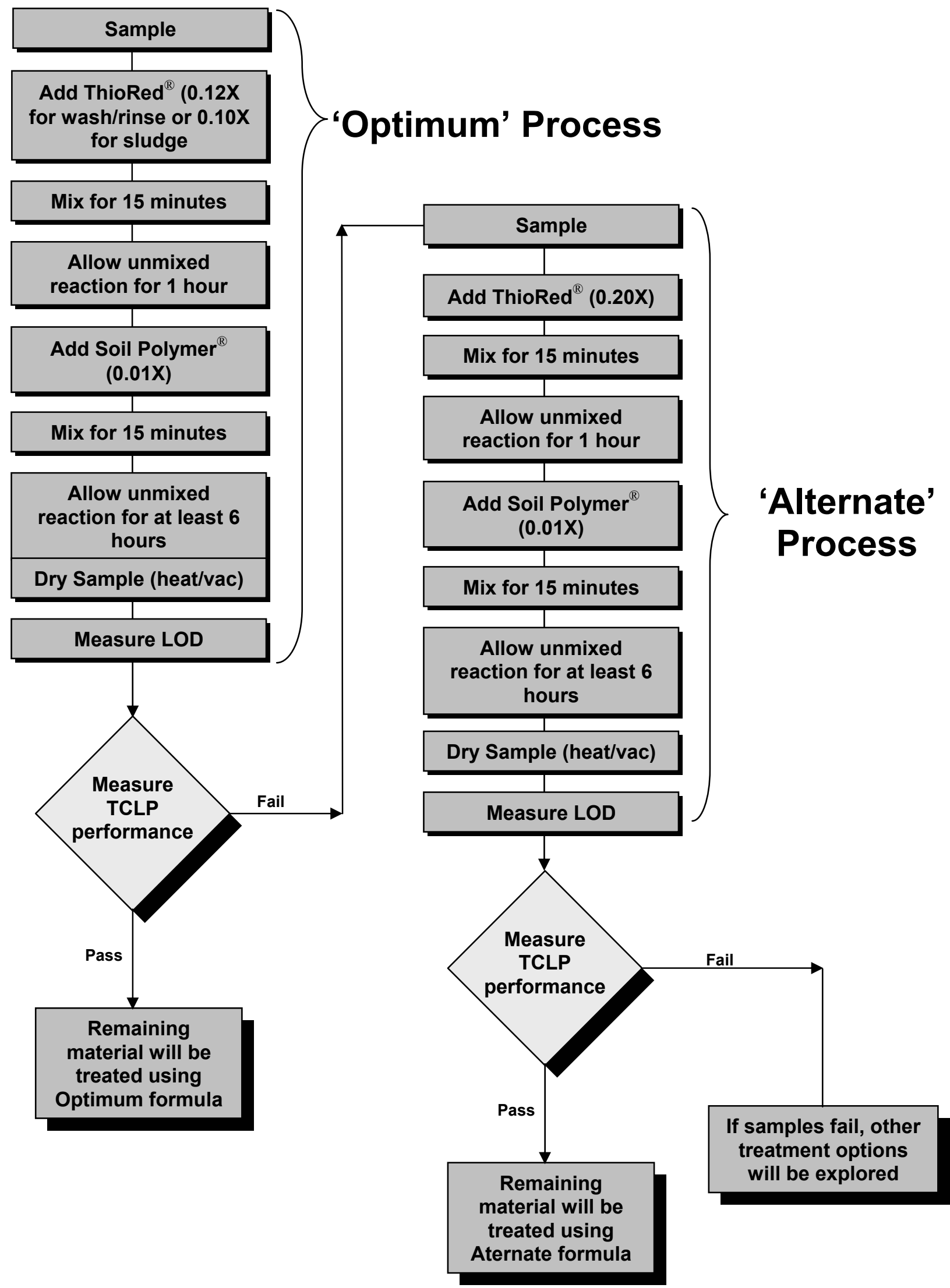

Fig. 2.3. Flowchart of chemical additive processing for the FWENC process. 


\section{EQUIPMENT, MATERIALS, AND TESTING METHODS}

\subsection{SURROGATES}

Two surrogates were used in this study. One is referred to as QnD (Quick and Dirty) surrogate, while the other is referred to as 'W23S', a highly representative surrogate for W23 Tank waste. The QnD surrogate formulation was based on a surrogate previously developed to mimic the weighted average chemical composition of MVST/BVEST Tank W23 using a simple mix of reagent grade chemicals, radionuclides, process metals, and water. A more representative surrogate, W23S, was prepared by mixing RCRA metal compounds, non-RCRA metal compounds, and radionuclide metal compounds - mainly nitrates - together followed by a sodium hydroxide precipitation $(\mathrm{pH} 11)$ of the component metals. A volume of water 1.5 times larger than the volume of the precipitated mixture was then used to remove soluble salts from the precipitate. The resulting filter cake and liquid filtrate were re-analyzed for both cation and anion components. The solids were then amended with the necessary amounts of requisite chemicals, including water, to bring the final composition to within 2\% (weight fraction) of actual W23 tank waste composition in more than 20 major constituents (both anion and cation). This surrogate was designed specifically for the actual W23 sludge sample to be used in hot testing. Tables 3.1 and 3.2 contain the ionic constituents and their concentrations for both surrogates and W23 sludge sample. Note that the sludge wash/rinse is not tank supernate; no actual tank supernates or surrogate tank supernates were tested in this work-just sludgewash solutions. During FWENC treatment of actual MVST tanks, however, sludge wash solution is to be combined with tank supernate, and then treated. The wash solution from any given tank is expected to be 5 times the volume of sludge in that tank.

\subsection{ACTUAL WASTES}

Tests were initiated on seven different actual tank wastes, including BVEST W23 and MVSTs W24, W25, W26, W27, W28, and W31. The MVST work, although not intended to start until FY 2001, was accelerated due to the Oak Ridge user schedule. After characterization, the FWENC 'Optimum' process (as described previously, and in Figs. 2.1, 2.2, and 2.3) was applied to the two worst-failing MVST tank samples and also to W23 tank waste. A 'Modified Optimum' process was applied to sludge wash/rinses. The 'Alternate' tests on actual sludges were not completed.

\subsection{PHYSICAL CONSIDERATIONS}

The wash/rinse from both surrogates was clear, tinted somewhat yellow (uranyl ion), and homogenous. QnD sludge was gray-pink and had the consistency of wet pancake batter. W23S sludge was bright yellow and also had a viscous but pourable consistency. A few larger particles were present that had a tendency to settle quickly after mixing. Pictures of the surrogate sludges and surrogate wash/rinse solutions, before and after, are presented in Figs. 3.1, 3.2, 3.3, 3.4, 3.5, 3.6, 3.7, and 3.8. 
Dried sludge surrogates having undergone the FWENC treatment process had the texture of soft chalk; these materials could be ground easily into a fine powder. Dried wash/rinse from the surrogates formed hard crystals. In both wash/rinse and sludge cases, the act of drying caused some chemical separation to occur in the samples, noticeably visible as stratification or layering in the dried samples.

Vacuum-assisted drying of wash/rinse liquids at $80^{\circ} \mathrm{C}$ took several days for open-faced containers, primarily due to the lack of convection within the vacuum oven. Additional airspace convection that could be generated during treatment would have speeded the drying process considerably - this was not, however, part of the FWENC process.

The final dried waste product from MVST Tank W28 looked very different from the other stabilized actual waste forms. Upon drying, it was granular, and did not form a 'cake' as did the other tank samples. Pictures of these dried samples can be found in Figs. 3.9, 3.10, and 3.11.

\subsection{INITIAL SAMPLE COLLECTION AND CHARACTERIZATION}

Sample collection from the MVST tanks was conducted by staff from the Liquid and Gaseous Waste Operations (LGWO), who delivered samples from six tanks to the Inorganic and Radiochemical Analytical Support Group within ORNL's Chemical and Analytical Sciences Division. Characterization, sampling location, and other property data are collected in Keller and Giaquinto (2001a, 2001b). Sample collection and characterization of samples taken from BVEST W23 tank can be found in Gilliam and Spence (1999) and Spence (1999).

\subsection{TCLP METHODS USED}

The standard EPA protocol (EPA Test Method 1311) outlining the procedure for obtaining leach data from solid waste forms recommends using $100 \mathrm{~g}$ of the waste form for each test. Roughly $300 \mathrm{~g}$ of sludge from each actual tank was available; it was also desirable to generate as little radioactive waste from both the actual and surrogate wasteforms. Therefore, a modified TCLP procedure, which used only $10 \mathrm{~g}$ of sample for both the surrogate and actual waste forms, was used. This modification is standard for TCLP analyses conducted at ORNL and results from this modification were validated as equivalent to a standard TCLP test.

\subsection{TCLP AND FREE WATER TESTING AT DESIGNATED INTERVALS}

\subsubsection{Conditions of Storage}

To simulate storage conditions that would be expected of a treated waste form in east Tennessee, we stored treated surrogate sludge samples in both conditioned (air conditioned) and unconditioned environments (a non-conditioned trailor) for nine months. The unconditioned environment was designed to be representative of changing ambient conditions in East Tennessee. Note: for East Tennessee, relative humidities vary from about 35 to $75 \%$ over the course of the year and normal weather, with some shortlived outliers associated with extreme weather conditions. Samples were pulled from this storage area 9 months after stabilization and examined for free water and TCLP performance. 


\subsubsection{Thermal Degradation Testing}

10 CFR 61.56 recommends that internal factors such as temperature and thermal effects be assessed to assure that a waste form retain stability. Thermal cycling of stabilized waste form is most likely to occur during storage and transport. By cycling between the maximum and minimum temperatures called for in the NRC's standardized thermal stability test for solid wastes, the extent of any degradation that might occur can be measured. Such degradation is a function of various factors, including the morphology of the microconstituents, the bond strength between the materials present, and the amount and types of cementitious additives present. We used this test primarily to explore the potential for free water appearance and TCLP performance change. Tests were conducted with W23S surrogate under both high humidity ( $75 \%$ or greater) and low humidity conditions (35\% or less). Specimens were placed in a thermal cycling test chamber for thirty cycles and allowed to come to thermal equilibrium at both the high $\left(60{ }^{\circ} \mathrm{C}\right)$ and low $\left(-40^{\circ} \mathrm{C}\right)$ temperature limits. Equilibration time at each temperature extreme was 1 hour. Three specimens were subjected to the thermal cycling tests for each humidity condition. Humidity was controlled by using saturated salt solutions (sodium chloride for $75 \%$ relative humidity and magnesium chloride for $30 \%$ ). 

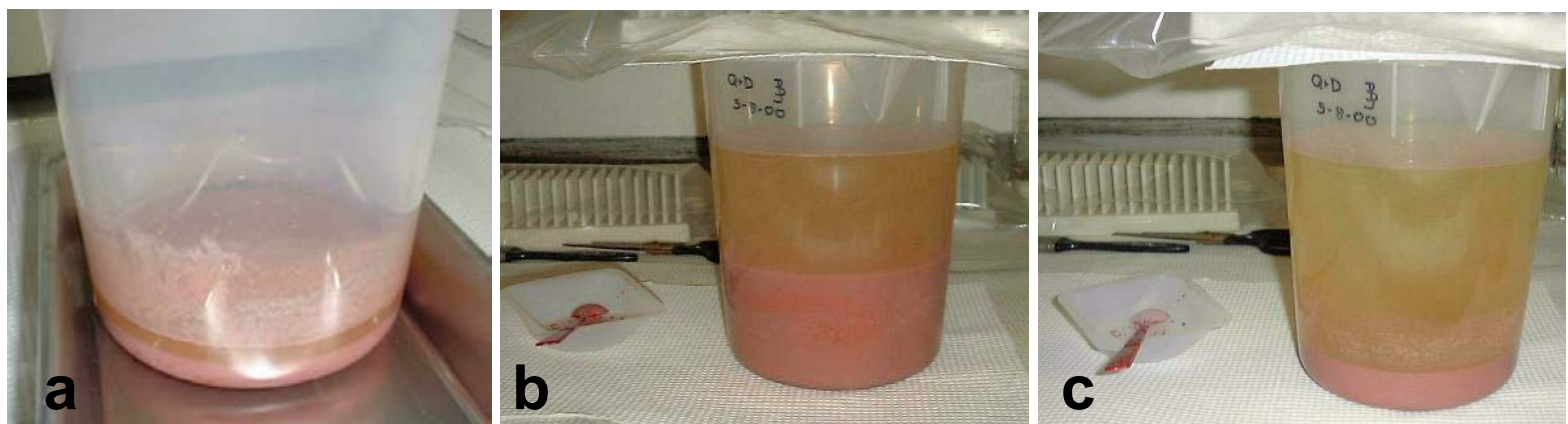

Fig. 3.1. (a) Quick and Dirty Surrogate, (b) QnD during wash/settling, (c) QnD after 12 hours of settling
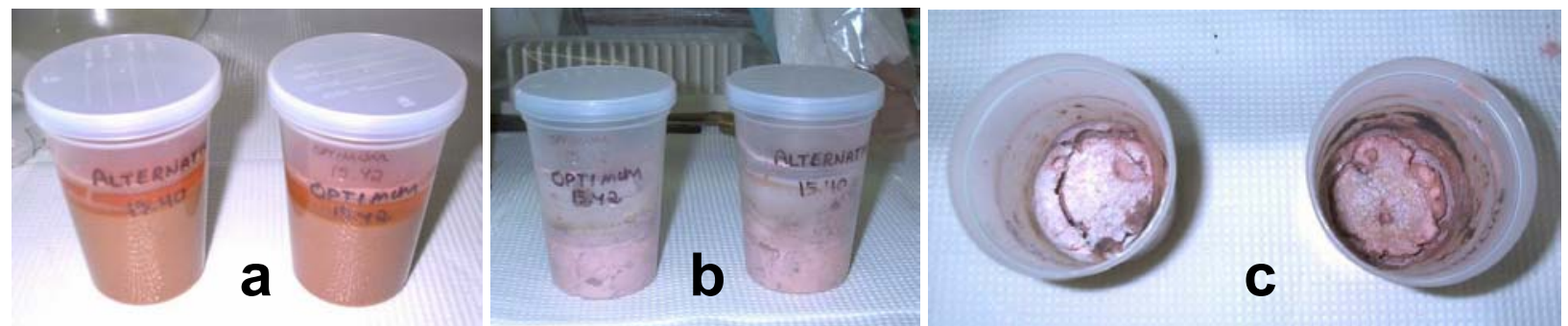

Fig. 3.2. (a) Rinsed QnD sludge after FWENC additives, before drying, (b) Rinsed QnD sludge after FWENC additives, after drying, and (c) Rinsed QnD sludge after FWENC additives, after drying, top view
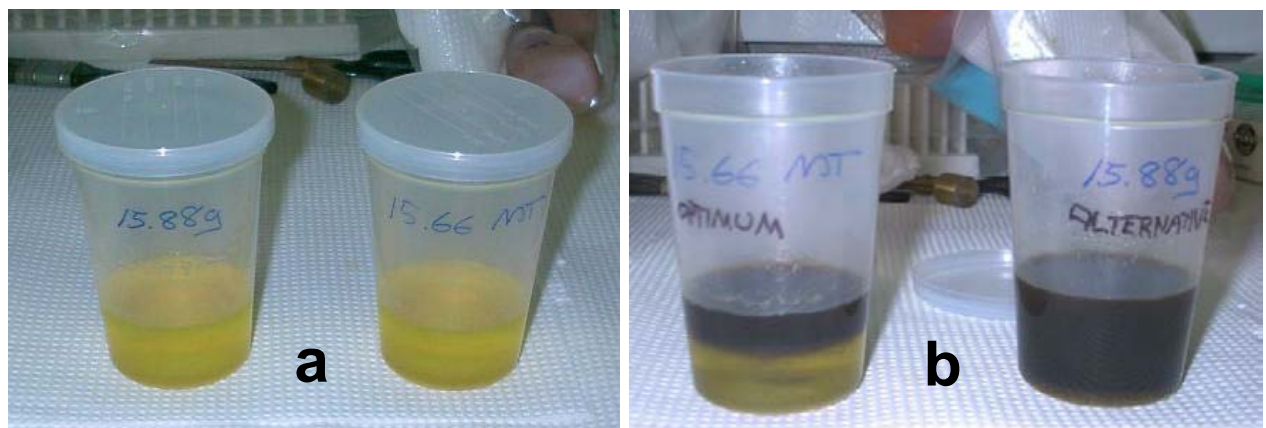

Fig. 3.3. (a) QnD wash/rinse, untreated, (b) QnD wash/rinse, after FWENC additive treatment, before drying
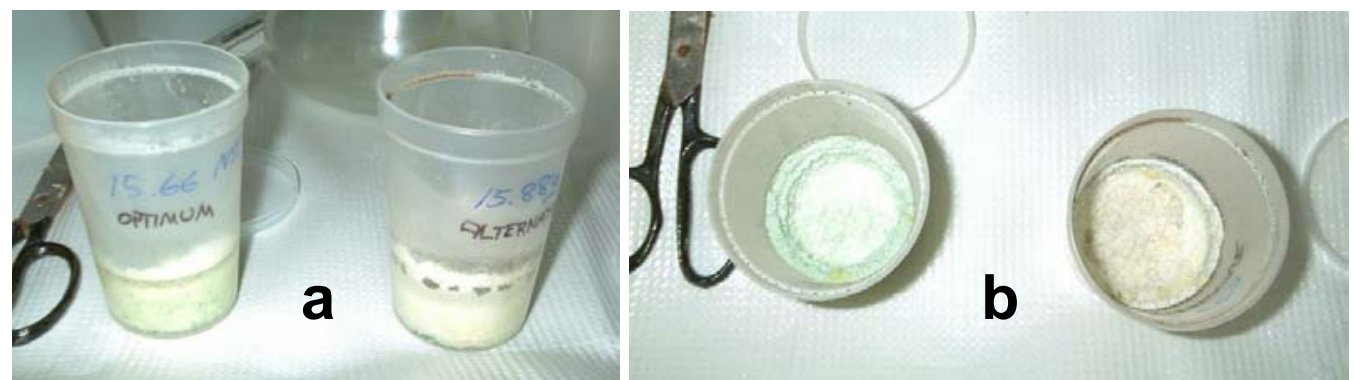

Fig. 3.4. (a) QnD wash/rinse, treated, after drying, (b) QnD wash/rinse, treated, after drying, top view 


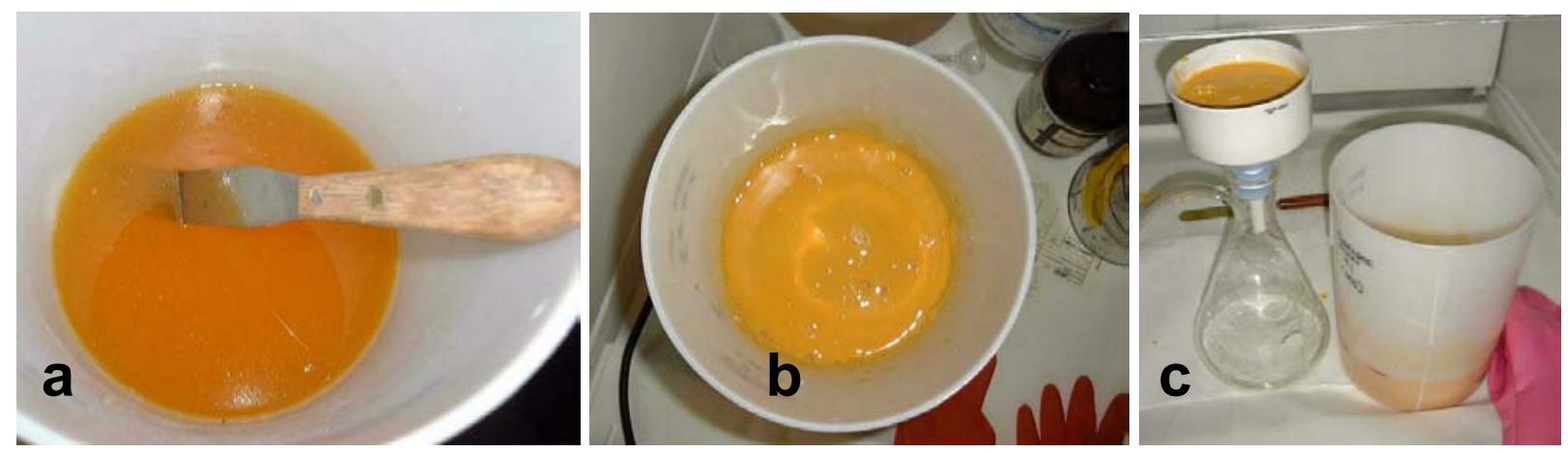

Fig. 3.5. (a) Preparation of W23S surrogate; mixture before precipitation, (b) Preparation of W23S surrogate; mixture after precipitation, (c) Preparation of W23S surrogate; filtration/rinse of precipitant
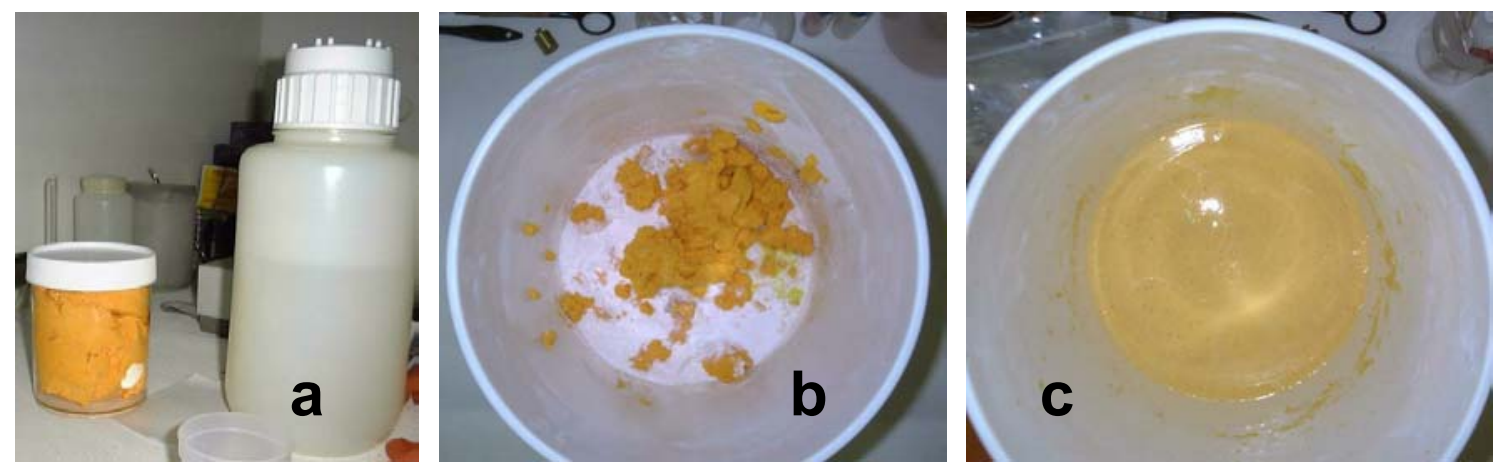

Fig. 3.6. (a) Preparation of W23S; filter cake and rinse, (b) Preparation of W23S; addition of chemicals to filter cake, (c) Final W23S surrogate
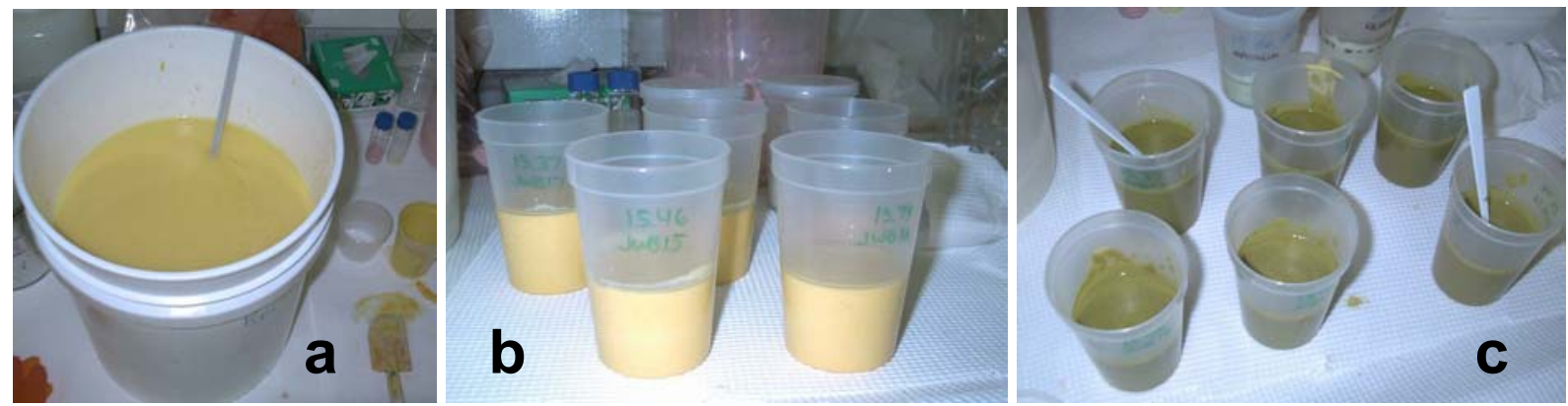

Fig. 3.7. (a) Wash of W23S surrogate, (b) Sludge from W23S before FWENC treatment, (c) Treated W23S sludge, before drying
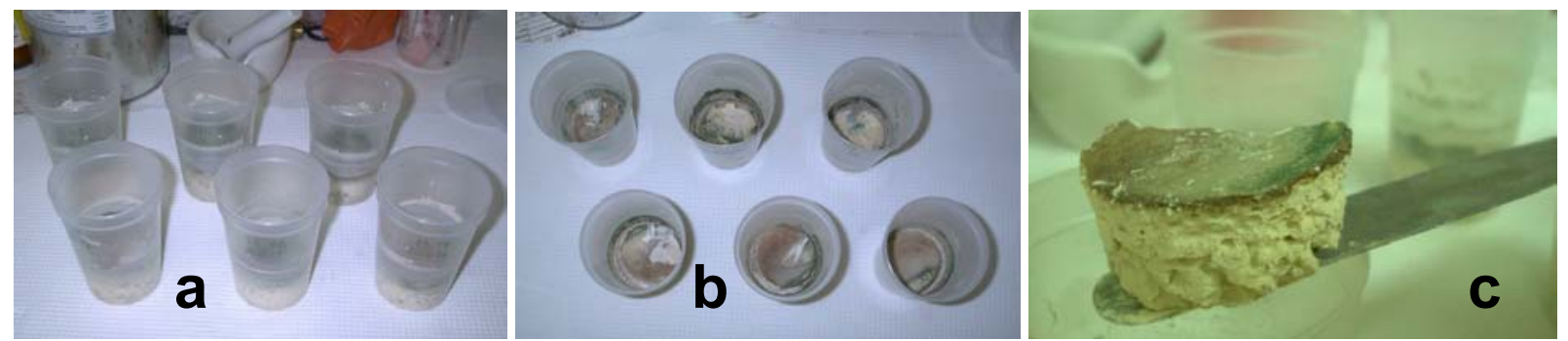

Fig. 3.8. (a) Treated W23S sludge after drying, (b) Treated W23S sludge after drying, top view, (c) Treated W23S sludge, stratification 

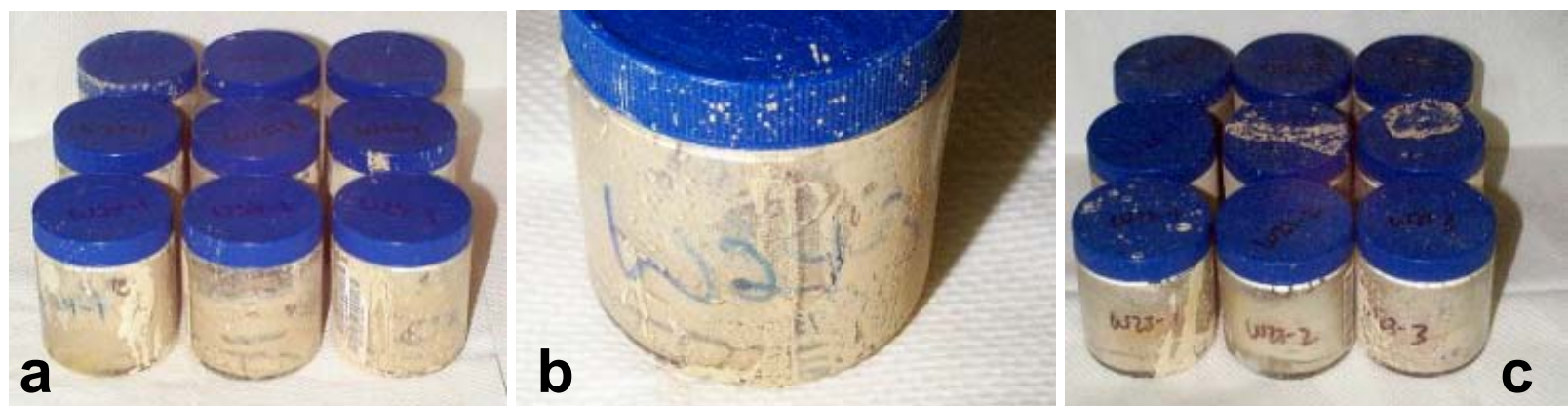

Fig. 3.9. (a) Dried MVST samples (W24, W25, W28) - no additives, (b) Close-up of dried W24 sample - no additives, (c) Dried W23 and MVST samples (W23, W26, W27) - optimum treatment applied
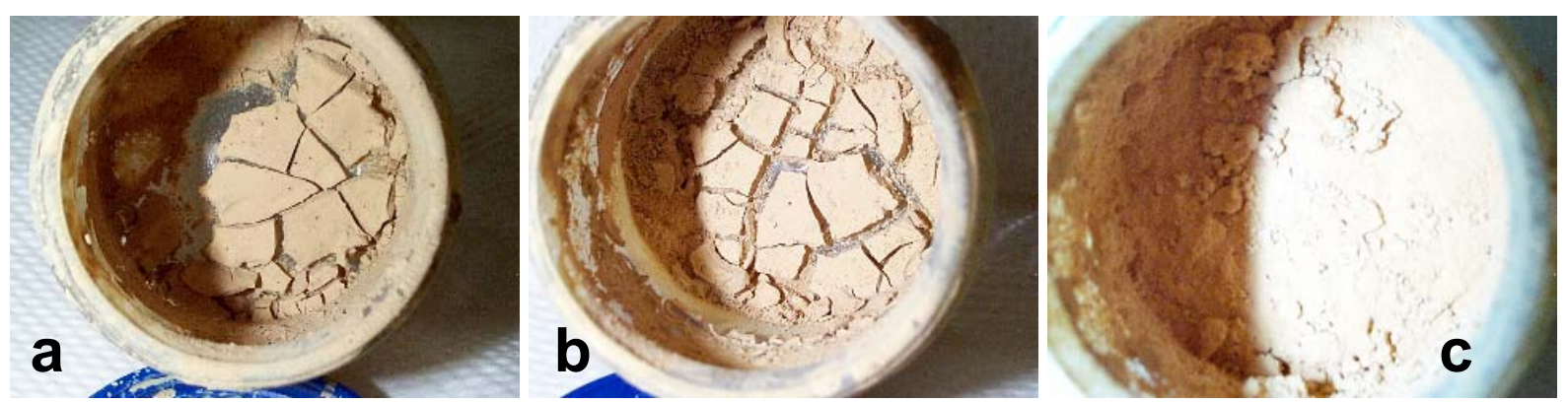

Fig. 3.10. (a) D ried MVST W24 sample - no additives, (b) Dried MVST W25 sample - no additives, (c) Dried MVST W28 sample - No additives. Note powdery appearance.
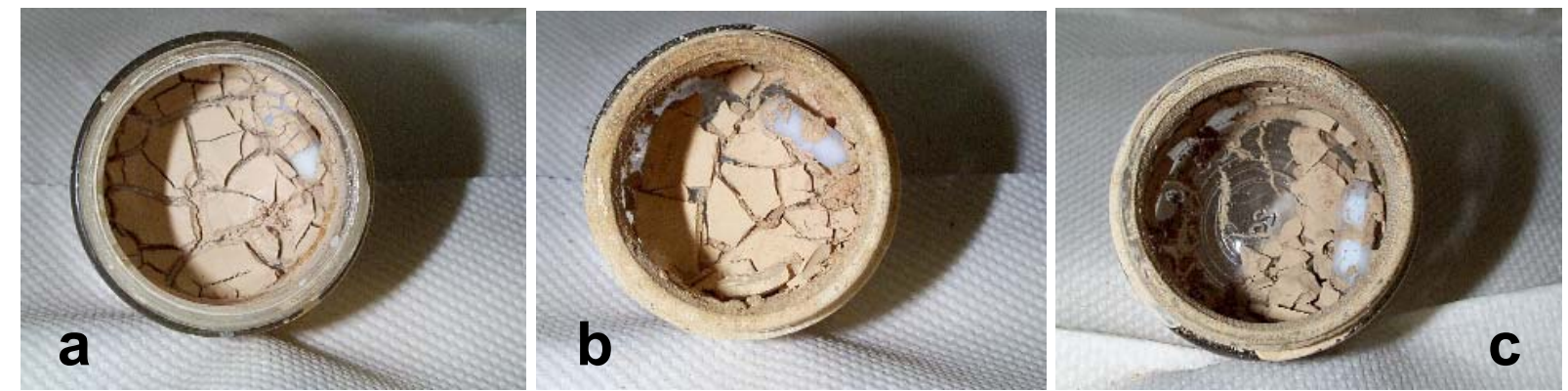

Fig. 3.11. (a) Dried MVST W23 sample - optimum treatment used. Sample jars also contained a stirring bar, which was added prior to drying to facilitate mixing of FWENC additives, (b) Dried MVST W26 sample - optimum treatment used, (c) Dried MVST W27 sample - optimum treatment used 
Table 3.1. QnD - 'Quick and Dirty' Surrogate Characterization and Comparison

\begin{tabular}{lrr}
\hline \multicolumn{1}{c}{ Component } & $\begin{array}{c}\text { Surrogate } \\
\text { Concentration (mg/kg } \\
\text { surrogate) }\end{array}$ & $\begin{array}{c}\text { W23 Sample Measured Concentration } \\
\text { (mg/kg waste) }\end{array}$ \\
\hline Cadmium & 51 & 24 \\
Chromium & 352 & 161 \\
Mercury & 76 & 35 \\
Lead & 1,539 & 705 \\
& & \\
Aluminum & 3,777 & 1,730 \\
Calcium & 124,236 & 56,900 \\
TIC & 14,399 & 1,320 \\
Iron & 3,777 & 1,730 \\
Potassium & 28,166 & 12,900 \\
Magnesium & 23,799 & 10,900 \\
Sodium & 127,074 & 58,200 \\
Nitrate & 174,236 & 79,800 \\
Nitrite & 18,537 & 8,490 \\
Chlorine & 11,397 & 5,220 \\
Fluorine & 1,777 & 814 \\
Sulfate & 19,891 & 9,110 \\
Strontium & 600 & 275 \\
Thorium & 35,808 & 16,400 \\
Uranium & 17,445 & 7,990 \\
Silicon & 4,672 & 2,140 \\
TOC & 6,253 & 1,550 \\
\hline & &
\end{tabular}


Table 3.2. W23S - Representative Surrogate Characterization and Comparison

\begin{tabular}{lcc}
\hline Component & $\begin{array}{c}\text { Surrogate Concentration } \\
\text { (mg/kg surrogate) }\end{array}$ & $\begin{array}{c}\text { W23 Sample Measured } \\
\text { Concentration (mg/kg waste) }\end{array}$ \\
\hline Cadmium & 24 & 24 \\
Chromium & 161 & 161 \\
Mercury & 37 & 35 \\
Lead & 711 & 705 \\
Aluminum & & \\
Calcium & 1,729 & 1,730 \\
Iron & 56,593 & 56,900 \\
Sulfate & 1,754 & 1,730 \\
Potassium & 9,170 & 9,110 \\
Nitrite & 12,838 & 12,900 \\
Magnesium & 8,416 & 8,490 \\
Sodium & 10,779 & 10,900 \\
Chloride & 58,613 & 58,200 \\
Fluoride & 5,151 & 5,220 \\
Silicon & 803 & 814 \\
Strontium & 2,134 & 2,140 \\
Nitrate & 277 & 275 \\
Thorium & 79,143 & 79,800 \\
Uranium & 16,710 & 16,400 \\
& 8,134 & 7,990 \\
TOC & 1,550 & 1,550 \\
\hline & & \\
\hline
\end{tabular}




\section{RESULTS FROM TESTING OF SURROGATE WASTES}

Without any treatment, both surrogates failed to pass TCLP for 3 RCRA metals - chromium, lead, and mercury. After the 'Optimum' FWENC treatment, the QnD surrogate passed (both the sludge and wash/rinse). After 'Optimum' treatment, the W23 surrogate (W23S) sludge passed. The wash/rinse passed (on average) after both 'Optimum', 'Alternate', and 'Modified Alternate', although some replicates failed in mercury. A matrix of pass/fails is shown as Table 0.1. Individual test results/concentrations are discussed below. Pictures of the final products, with descriptions, may be found in Figs. 3.1, 3.2, 3.3, 3.4, 3.5, 3.6, 3.7, and 3.8.

\subsection{RESULTS FROM TESTING QnD SURROGATE}

\subsubsection{Results From Testing of 'Wet' Surrogate}

After the two fractions (sludge and wash/rinse) were separated from the initial washing step, the untreated sludge was submitted for wet TCLP testing and the wash/rinse was analyzed for its ionic constituents. The sludge was found to fail chromium, lead, and mercury TCLP limits. The wash/rinse, by conservative calculation, was also found to fail in chromium, lead, and mercury. Of note was that a substantial amount of uranium remained suspended/soluble even at high $\mathrm{pH}$. Wash/rinse levels after a theoretical TCLP were $>9 \mathrm{mg} \mathrm{U} / \mathrm{L}$. Wet results data can be found in Tables 4.1 and 4.2 .

\subsubsection{Results from 'Optimum' Treatment of QnD Surrogate}

Based on the above 'wet' results, the FWENC process requires that both the wash/rinse and sludge be treated using the 'Optimum' formulation of additives. The treatment process worked well for both components of this surrogate, which passed TCLP after treatment. Tables 4.3 and 4.4 show leach concentrations from these tests. Additives had a profound effect on mercury in both the sludge and wash/rinse, reducing leachable concentration by several orders of magnitude. Other metals were also stabilized; concentrations of lead in the TCLP leaches were closer than any of the other metals to failure, at levels near 1 ppm (RCRA limit: 5 ppm).

\subsubsection{Results from 'Alternate' Treatment of QnD Surrogate}

Based on the above 'Optimum' results, the FWENC process diagram did not require that the wash/rinse and sludge be treated using the 'Alternate' formulation of additives. Due to time constraints, 'Optimum' and 'Alternate' processing of surrogates were conducted in parallel, rather than sequentially as prescribed by the FWENC process. We present these data for completeness. After the 'Alternate' treatment, the surrogate passed TCLP requirements on all four RCRA components. Data are shown in Tables 4.5 and 4.6.

\subsection{RESULTS FROM TESTING W23S SURROGATE}

\subsubsection{Results From Testing of 'Wet' Surrogate}

After the two fractions (sludge and wash/rinse) were separated from the initial washing step, the untreated sludge was subjected to a wet TCLP analysis and the wash/rinse was analzyed for ionic constituents. The sludge was found to fail mercury, chromium, and lead (see Table 4.7). The wash/rinse, by calculation, had the potential to fail TCLP in chromium, lead, and mercury after drying (see Table 4.8). If the dried product is projected to fail TCLP, the FWENC procedure mandates stabilizer addition prior to drying. Hence, stabilizer addition was required per FWENC for both the rinsed W23S surrogate sludge and its washwater, based on the results listed in Tables 4.7 and 4.8 . 


\subsubsection{Results From Testing of Dried Sludge}

Although the FWENC process does not require dry, untreated sludge to be TCLP tested unless the wet sludge passes the test, we ran the dry test for comparative purposes to see what might be expected. Interestingly, the dry, untreated sludge failed only in mercury (see Table 4.9), whereas wet W23S surrogate sludge failed additionally in chromium and lead.

\subsubsection{Results from 'Optimum' Treatment of W23S Surrogate}

Based on the 'wet' results above, the FWENC process required that both the wash/rinse and sludge be treated using the 'Optimum' formulation of additives. After treatment, the sludge passed TCLP limits on the four RCRA metals (see Table 4.10). The wash/rinse initially failed in mercury during an initial set of triplicate tests (Table 4.11a). A second set of triplicate experiments, however, showed that the 'Optimum' process could stabilize the rinse (see Table 4.11b).

\subsubsection{Results from 'Alternate' Treatment of W23S Surrogate}

Based on the above results, the FWENC process required that only the wash/rinse be treated using the 'Alternate' formulation of additives. Since our experiments were conducted in parallel, we present the 'Alternate' process on the sludge as well. The sludge passed easily, as expected (Table 4.12). The wash/rinse failed in mercury during one set of triplicate experiments (Table 4.13a), but passed in a subsequent set (Table 4.13b).

\subsubsection{Results from 'Modified Optimum' and 'Modified Alternate' Treatment of W23S Surrogate}

The 'Modified' FWENC process is identical to the normal process with one exception: chemical additives are mixed in with the waste prior to the evaporation step. In general, the 'Modified' process worked better for stabilizing mercury than the standard process with an order of magnitude enhancement. The 'Modified' process did not significantly alter cadmium concentrations in the leach, but did lower lead levels by roughly three-fold. Individual results are listed in Table 4.14.

\subsection{UTS CONSIDERATIONS}

Universal Treatment Standards/regulations (i.e., Land Disposal Restrictions) significantly affect the disposal criterion for many of the RCRA metals, some of which are listed in Table 4.15. UTS limits are constituent-specific standards that apply generally to all wastes, rather than being waste-specific standards that apply only to a specific waste stream. The amended UTS limits for characteristically toxic metal wastes established in the rule are generally more stringent than the characteristic levels. In addition, any underlying metal or organic hazardous constituents contained in these wastes must also be treated to meet the applicable Land Disposal Restriction standard, regardless of whether the concentration exceeds a TC threshold.

Based on UTS criteria, neither the QnD nor W23S surrogates would pass after the prescribed FWENC treatments. Primary failure after treatment was in concentration of lead. A matrix of those results can be found in Table 4.16. 
Table 4.1. TCLP concentrations of metals and radionuclides for 'quick and dirty' surrogate wet sludge.

\begin{tabular}{lcc}
\hline \multicolumn{1}{c}{ Component } & $\begin{array}{c}\text { Measured Concentration } \\
(\mathrm{mg} / \mathrm{L})\end{array}$ & $\begin{array}{c}\text { RCRA Characteristic Limit Concentration } \\
(\mathrm{mg} / \mathrm{L})\end{array}$ \\
\hline Cadmium & 0.001 & 1.0 \\
Chromium & $\mathbf{1 1 . 6 9}$ & 5.0 \\
Mercury & $\mathbf{1 . 1 2 3}$ & 0.2 \\
Lead & $\mathbf{1 2 . 9 1}$ & 5.0 \\
Uranium & 0.083 & Not applicable \\
Thorium & $<0.500$ & Not applicable \\
\hline
\end{tabular}

Table 4.2. Calculated TCLP concentrations of metals and radionuclides for 'quick and dirty' surrogate wash/rinse. For pure liquids, ionic analysis was used to simulate the FWENC drying process, followed by a theoretical dissolution of the salts in the standard 20X TCLP leach volume that would be used. These calculations were only necessary for the initial wet tests of both surrogate washes.

\begin{tabular}{lcc}
\hline Component & $\begin{array}{c}\text { Calculated TCLP Leach } \\
\text { Concentration (mg/L) based } \\
\text { on ionic analysis }\end{array}$ & $\begin{array}{c}\text { RCRA Characteristic Limit Concentration } \\
(\mathrm{mg} / \mathrm{L})\end{array}$ \\
\hline Cadmium & $<0.002$ & 1.0 \\
Chromium & $\mathbf{2 8 . 4 8}$ & 5.0 \\
Mercury & $\mathbf{1 . 5 2 2}$ & 0.2 \\
Lead & $\mathbf{2 6 . 5 0}$ & 5.0 \\
Uranium & 9.19 & Not applicable \\
Thorium & $<0.500$ & Not applicable \\
\hline
\end{tabular}

Table 4.3. TCLP leach concentrations of metals and radionuclides for QnD stabilized sludge surrogate-'Optimum' treatment (averages of triplicate TCLP).

\begin{tabular}{lrc}
\hline \multicolumn{1}{c}{ Component } & $\begin{array}{c}\text { Measured Concentration } \\
(\mathrm{mg} / \mathrm{L})\end{array}$ & $\begin{array}{c}\text { RCRA Characteristic Limit Concentration } \\
(\mathrm{mg} / \mathrm{L})\end{array}$ \\
\hline Cadmium & $<0.002$ & 1.0 \\
Chromium & 0.539 & 5.0 \\
Mercury & 0.000091 & 0.2 \\
Lead & 0.862 & 5.0 \\
Uranium & 5.30 & Not applicable \\
Thorium & 1.67 & Not applicable \\
\hline
\end{tabular}


Table 4.4. TCLP leach concentrations of metals and radionuclides for QnD stabilized wash/rinse-'Optimum' treatment.

\begin{tabular}{lrc}
\hline \multicolumn{1}{c}{ Component } & $\begin{array}{r}\text { Measured Concentration } \\
(\mathrm{mg} / \mathrm{L})\end{array}$ & $\begin{array}{c}\text { RCRA Characteristic Limit Concentration } \\
(\mathrm{mg} / \mathrm{L})\end{array}$ \\
\hline Cadmium & 0.009 & 1.0 \\
Chromium & 0.194 & 5.0 \\
Mercury & 0.000968 & 0.2 \\
Lead & 1.154 & 5.0 \\
Uranium & 0.409 & Not applicable \\
Thorium & $<0.500$ & Not applicable \\
\hline
\end{tabular}

Table 4.5. TCLP concentrations of metals and radionuclides for QnD stabilized surrogate - 'alternate' treatment (averages of triplicate TCLP).

\begin{tabular}{lrc}
\hline \multicolumn{1}{c}{ Component } & $\begin{array}{c}\text { Measured Concentration } \\
(\mathrm{mg} / \mathrm{L})\end{array}$ & $\begin{array}{c}\text { RCRA Characteristic Limit Concentration } \\
(\mathrm{mg} / \mathrm{L})\end{array}$ \\
\hline Cadmium & 0.016 & 1.0 \\
Chromium & 1.0557 & 5.0 \\
Mercury & 0.000352 & 0.2 \\
Lead & 1.409 & 5.0 \\
Uranium & 9.917 & Not applicable \\
Thorium & 4.907 & Not applicable \\
\hline
\end{tabular}

Table 4.6. TCLP concentrations of metals and radionuclides for QnD stabilized wash/rinse- 'alternate' treatment (averages of triplicate TCLP).

\begin{tabular}{lrc}
\hline \multicolumn{1}{c}{ Component } & $\begin{array}{r}\text { Measured Concentration } \\
(\mathrm{mg} / \mathrm{L})\end{array}$ & $\begin{array}{c}\text { RCRA Characteristic Limit Concentration } \\
(\mathrm{mg} / \mathrm{L})\end{array}$ \\
\hline Cadmium & 0.009 & 1.0 \\
Chromium & 0.174 & 5.0 \\
Mercury & 0.004187 & 0.2 \\
Lead & 1.225 & 5.0 \\
Uranium & 0.446 & Not applicable \\
Thorium & $<0.500$ & Not applicable \\
\hline
\end{tabular}


Table 4.7. TCLP concentrations of metals and radionuclides for W23S surrogate wet sludge (averages of triplicate TCLP).

\begin{tabular}{lrc}
\hline \multicolumn{1}{c}{ Component } & $\begin{array}{r}\text { Measured concentration } \\
(\mathrm{mg} / \mathrm{L})\end{array}$ & $\begin{array}{c}\text { RCRA characteristic limit Concentration } \\
(\mathrm{mg} / \mathrm{L})\end{array}$ \\
\hline Cadmium & 0.0059 & 1.0 \\
Chromium & $\mathbf{1 7 . 5 2 4}$ & 5.0 \\
Mercury & $\mathbf{1 . 7 8 5}$ & 0.2 \\
Lead & $\mathbf{1 3 . 5 3}$ & 5.0 \\
Uranium & 1.14 & Not applicable \\
Thorium & 1.662 & Not applicable \\
\hline
\end{tabular}

Table 4.8. Theoretical leach TCLP concentrations of metals and radionuclides for $\mathrm{W} 23 \mathrm{~S}$ surrogate wash/rinse (based on analysis of wash/rinse; assumes complete dissolution). For pure liquids, ionic analysis was used to simulate the FWENC drying process, followed by a theoretical dissolution of the salts in the standard 20X TCLP leach volume that would be used. These calculations were only necessary for the initial wet tests of both surrogate washes.

\begin{tabular}{lcc}
\hline Component & $\begin{array}{c}\text { Calculated TCLP Leach } \\
\text { Concentration (mg/L) based } \\
\text { on ionic analysis }\end{array}$ & $\begin{array}{c}\text { RCRA Characteristic Limit Concentration } \\
(\mathrm{mg} / \mathrm{L})\end{array}$ \\
\hline Cadmium & $<0.002$ & 1.0 \\
Chromium & $\mathbf{2 4 . 0 2 6}$ & 5.0 \\
Mercury & $\mathbf{1 . 5 1 0}$ & 0.2 \\
Lead & $\mathbf{1 3 . 6 7 2}$ & 5.0 \\
Uranium & 2.473 & Not applicable \\
Thorium & $<0.500$ & Not applicable \\
\hline
\end{tabular}

Table 4.9. TCLP concentrations of metals and radionuclides for W23S Surrogate Dry Sludge-Untreated (averages of triplicate TCLP).

\begin{tabular}{lcc}
\hline \multicolumn{1}{c}{ Component } & $\begin{array}{c}\text { Measured Concentration } \\
(\mathrm{mg} / \mathrm{L})\end{array}$ & $\begin{array}{c}\text { RCRA Characteristic Limit Concentration } \\
(\mathrm{mg} / \mathrm{L})\end{array}$ \\
\hline Cadmium & 0.007 & 1.0 \\
Chromium & 2.717 & 5.0 \\
Mercury & $\mathbf{0 . 6 2 1}$ & 0.2 \\
Lead & 0.960 & 5.0 \\
Uranium & 0.110 & Not applicable \\
Thorium & 0.193 & Not applicable \\
\hline
\end{tabular}


Table 4.10. TCLP concentrations of metals and radionuclides for $W 23 S$ Stabilized Surrogate-'Optimum' treatment (averages of triplicate TCLP).

\begin{tabular}{lcc}
\hline \multicolumn{1}{c}{ Component } & $\begin{array}{c}\text { Measured Concentration } \\
(\mathrm{mg} / \mathrm{L})\end{array}$ & $\begin{array}{c}\text { RCRA Characteristic Limit Concentration } \\
(\mathrm{mg} / \mathrm{L})\end{array}$ \\
\hline Cadmium & 0.005 & 1.0 \\
Chromium & 0.379 & 5.0 \\
Mercury & 0.000702 & 0.2 \\
Lead & 0.861 & 5.0 \\
Uranium & 0.248 & Not applicable \\
Thorium & 0.222 & Not applicable \\
\hline
\end{tabular}

Table 4.11a. TCLP concentrations of metals and radionuclides for W23S stabilized wash/rinse—'Optimum' treatment, average of three initial triplicates.

\begin{tabular}{lcc}
\hline \multicolumn{1}{c}{ Component } & $\begin{array}{c}\text { Measured Concentration } \\
(\mathrm{mg} / \mathrm{L})\end{array}$ & $\begin{array}{c}\text { RCRA Characteristic Limit Concentration } \\
(\mathrm{mg} / \mathrm{L})\end{array}$ \\
\hline Cadmium & $<0.002$ & 1.0 \\
Chromium & 0.367 & 5.0 \\
Mercury & $\mathbf{0 . 2 6 7}$ & 0.2 \\
Lead & 0.284 & 5.0 \\
Uranium & 1.51 & Not applicable \\
Thorium & 1.41 & Not applicable \\
\hline
\end{tabular}

Table 4.11b. TCLP concentrations of metals and radionuclides for $W 23 \mathrm{~S}$ stabilized wash/rinse_-'Optimum' treatment, average of three later triplicates.

\begin{tabular}{lrc}
\hline \multicolumn{1}{c}{ Component } & $\begin{array}{r}\text { Measured Concentration } \\
(\mathrm{mg} / \mathrm{L})\end{array}$ & $\begin{array}{r}\text { RCRA Characteristic Limit Concentration } \\
(\mathrm{mg} / \mathrm{L})\end{array}$ \\
\hline Cadmium & 0.021 & 1.0 \\
Chromium & NonDetect & 5.0 \\
Mercury & 0.021 & 0.2 \\
Lead & 2.122 & 5.0 \\
Uranium & 0.404 & Not applicable \\
Thorium & 5.68 & Not applicable \\
\hline
\end{tabular}


Table 4.12. TCLP concentrations of metals and radionuclides for W23S Stabilized Surrogate-'Alternate' treatment (averages of triplicate TCLP).

\begin{tabular}{lrc}
\hline \multicolumn{1}{c}{ Component } & $\begin{array}{c}\text { Measured Concentration } \\
(\mathrm{mg} / \mathrm{L})\end{array}$ & $\begin{array}{c}\text { RCRA Characteristic Limit Concentration } \\
(\mathrm{mg} / \mathrm{L})\end{array}$ \\
\hline Cadmium & 0.006 & 1.0 \\
Chromium & 0.455 & 5.0 \\
Mercury & 0.000655 & 0.2 \\
Lead & 0.972 & 5.0 \\
Uranium & 0.172 & Not applicable \\
Thorium & 1.037 & Not applicable \\
\hline
\end{tabular}

Table 4.13a. TCLP concentrations of metals and radionuclides for W23S stabilized wash/rinse-'Alternate' treatment (averages of initial triplicate TCLP).

\begin{tabular}{lcc}
\hline \multicolumn{1}{c}{ Component } & $\begin{array}{c}\text { Measured Concentration } \\
(\mathrm{mg} / \mathrm{L})\end{array}$ & $\begin{array}{c}\text { RCRA Characteristic Limit Concentration } \\
(\mathrm{mg} / \mathrm{L})\end{array}$ \\
\hline Cadmium & $<0.002$ & 1.0 \\
Chromium & 0.107 & 5.0 \\
Mercury & $\mathbf{0 . 8 1 8 ^ { a }}$ & 0.2 \\
Lead & $<0.010$ & 5.0 \\
Uranium & 1.51 & Not applicable \\
Thorium & 1.20 & Not applicable \\
\hline
\end{tabular}

${ }^{a}$ Standard deviation on triplicate sample was 0.038 .

Table 4.13b. TCLP concentrations of metals and radionuclides for W23S stabilized wash/rinse- 'Alternate' treatment (averages of a later triplicate TCLP).

\begin{tabular}{lrr}
\hline Component & $\begin{array}{c}\text { Measured Concentration } \\
(\mathrm{mg} / \mathrm{L})\end{array}$ & $\begin{array}{c}\text { RCRA Characteristic Limit Concentration } \\
(\mathrm{mg} / \mathrm{L})\end{array}$ \\
\hline Cadmium & 0.019 & 1.0 \\
Chromium & NonDetect & 5.0 \\
Mercury & $\mathbf{0 . 0 2 1}$ & 0.2 \\
Lead & 1.34 & 5.0 \\
Uranium & 0.268 & Not applicable \\
Thorium & NonDetect & Not applicable \\
\hline
\end{tabular}


Table 4.14. Matrix of surrogate results

\begin{tabular}{|c|c|c|c|c|c|c|c|}
\hline \multirow[b]{2}{*}{$\begin{array}{l}\text { W23S surrogate rinse } \\
\text { TCLP }\end{array}$} & \multicolumn{7}{|c|}{ Leach data } \\
\hline & $\begin{array}{l}\text { Mercury } \\
(\mu \mathrm{g} / \mathrm{L})\end{array}$ & $\begin{array}{l}\text { Cadmium } \\
(\mathrm{mg} / \mathrm{L})\end{array}$ & $\begin{array}{l}\text { Chromium } \\
(\mathrm{mg} / \mathrm{L})\end{array}$ & $\begin{array}{l}\text { Lead } \\
(\mathrm{mg} / \mathrm{L})\end{array}$ & $\begin{array}{l}\text { Strontium } \\
(\mathrm{mg} / \mathrm{L})\end{array}$ & $\begin{array}{l}\text { Uranium } \\
(\mathrm{mg} / \mathrm{L})\end{array}$ & $\begin{array}{l}\text { Thorium } \\
(\mathrm{mg} / \mathrm{L})\end{array}$ \\
\hline Optimum 1 & 35.700 & 0.020 & ND & 2.445 & 32.644 & ND & ND \\
\hline Optimum 2 & 18.300 & 0.021 & ND & 2.299 & 31.245 & 0.853 & 6.14 \\
\hline Optimum 2 duplicate & 15.200 & 0.020 & ND & 2.104 & 33.783 & 0.764 & 6.08 \\
\hline Optimum 3 & 15.700 & 0.021 & ND & 1.640 & 32.757 & ND & 5.68 \\
\hline Optimum average & 21.225 & 0.021 & & 2.122 & 32.607 & 0.404 & 4.475 \\
\hline Alternative 1 & 56.000 & 0.019 & ND & 2.141 & 30.960 & ND & ND \\
\hline Alternative 2 & 7.920 & 0.018 & ND & 0.860 & 29.891 & 0.804 & ND \\
\hline Alternative 3 & 0.524 & 0.021 & ND & 1.012 & 31.087 & ND & ND \\
\hline Alternative average & 21.481 & 0.019 & & 1.338 & 30.646 & 0.268 & 0.000 \\
\hline Mod. optimum 1 & 0.431 & 0.022 & ND & 0.799 & 37.266 & 1.001 & 5.41 \\
\hline Mod. optimum 2 & 0.430 & 0.022 & ND & 0.580 & 35.597 & 1.154 & 5.51 \\
\hline Mod. optimum 3 & 3.640 & 0.020 & ND & 0.686 & 31.752 & 1.095 & 6.25 \\
\hline Mod. optimum average & 1.500 & 0.021 & & 0.688 & 34.872 & 1.083 & 5.723 \\
\hline Mod. alternative 1 & 0.568 & 0.020 & ND & 0.546 & 33.247 & ND & ND \\
\hline Mod. alternative 2 & 0.601 & 0.019 & ND & 0.765 & 32.459 & 1.383 & 5.03 \\
\hline Mod. alternative 3 & 0.890 & 0.020 & ND & 0.713 & 34.080 & 1.028 & ND \\
\hline Mod. alternative average & 0.686 & 0.020 & & 0.675 & 33.262 & 0.804 & 1.677 \\
\hline Drying only & 0.180 & 0.023 & ND & 1.898 & 38.203 & 1.468 & 6.06 \\
\hline Drying only & 2.960 & 0.020 & ND & 2.632 & 34.424 & 1.051 & 5.64 \\
\hline Nine month storage 1 & 0.495 & 0.000 & 0.252 & 0.595 & 10.805 & ND & ND \\
\hline Nine month storage 2 & 0.295 & 0.000 & 0.209 & 0.543 & 10.538 & ND & ND \\
\hline Nine month storage 3 & 0.578 & 0.000 & 0.228 & 0.510 & 9.971 & 0.722 & ND \\
\hline
\end{tabular}


Table 4.15. Comparison of RCRA Versus UTS Criteria

\begin{tabular}{lcc}
\hline \multicolumn{1}{c}{ Component } & $\begin{array}{c}\text { EPA characteristic limit } \\
\text { concentration }(\mathrm{mg} / \mathrm{L})\end{array}$ & Universal Treatment Standard $(\mathrm{mg} / \mathrm{L})$ \\
\hline Cadmium & 1.0 & 0.11 \\
Chromium & 5.0 & 0.6 \\
Mercury & 0.2 & 0.025 \\
Lead & 5.0 & 0.75 \\
Uranium & Not applicable & Not applicable \\
Thorium & Not applicable & Not applicable \\
\hline
\end{tabular}

Table 4.16. TCLP pass/failures of the various surrogate components after specific treatments based on UTS specifications. These pass/fail criteria only consider RCRA metals, not the radionuclide leach concentrations. Although the FWENC process markedly reduced RCRA metals concentrations, it was not able to bring all metals below UTS limits.

\begin{tabular}{|c|c|c|c|c|}
\hline Surrogate & Wet TCLP/analysis & $\begin{array}{c}\text { Dried waste form (no } \\
\text { additives) }\end{array}$ & $\begin{array}{l}\text { Optimum } \\
\text { treatment }\end{array}$ & $\begin{array}{l}\text { Alternate } \\
\text { treatment }\end{array}$ \\
\hline QnD Sludge & Fail $(\mathrm{Pb}, \mathrm{Cr}, \mathrm{Hg})$ & Not Tested & Fail $(\mathrm{Pb})$ & Fail $(\mathrm{Pb}, \mathrm{Cr})$ \\
\hline QnD Wash/Rinse & Fail $(\mathrm{Pb}, \mathrm{Cr}, \mathrm{Hg})$ & Not Tested & Fail $(\mathrm{Pb})$ & Fail $(\mathrm{Pb})$ \\
\hline W23S Sludge & Fail (Pb, Cr, Hg) & Fail $(\mathrm{Pb}, \mathrm{Cr}, \mathrm{Hg})$ & Fail $(\mathrm{Pb})$ & Fail $(\mathrm{Pb})$ \\
\hline W23S Wash/Rinse & Fail $(\mathrm{Pb}, \mathrm{Cr}, \mathrm{Hg})$ & Not Tested & Fail (Hg) & Fail (Hg) \\
\hline
\end{tabular}




\section{RESULTS FROM TESTING OF ACTUAL TANK WASTES}

\subsection{RESULTS FROM TESTING OF W23 ACTUAL TANK WASTE}

\subsubsection{Results from Testing of Sludge}

Triplicate W23 tank samples were treated using the FWENC proposed treatment plan. Pictures of the final waste form, treated with the 'Optimum' formulation, are shown as Figs. 3.9 and 3.11. The sludge surrogate passed TCLP testing before and after treatment, as did the sludge rinse (see Fig. 5.7 for specific data and additional commentary). This result mirrored the work that had been conducted with the representative W23 surrogate (W23S).

\subsubsection{Results from Testing of Wash/Rinse}

Two TCLP assays were run on wash/rinse from W23 tank samples. One of these tests involved simple drying of the wash/rinse (no chemical addition). The other test involved using the 'Modified' Optimum FWENC process (chemical addition). Cadmium reached $66 \%$ of the leach limit in the sludge rinse when subjected to simple drying; this level dropped to $35 \%$ after chemical additives were applied. When the FWENC additives were added to the rinse (using the 'Modified Optimum' process), decreased leach levels of cadmium (by 48\%), chromium (96\%), mercury (nearly 100\%), and lead (16\%) were observed.

\subsection{RESULTS FROM TESTING OF MVST ACTUAL TANK WASTE SLUDGE}

Three of the six MVST sludge samples failed a wet TCLP test after being washed with water. All untreated wash/rinses failed TCLP based on composition calculations (Figs. 5.1 through 5.13). All failures were in mercury or cadmium. See Table 5.1 for an abbreviated matrix. The FWENC procedure required testing of the two worst-failing sludges, which were taken from W26 and W27. These samples were subjected to the 'Optimum' FWENC process. Dry, untreated TCLP measurements were also made on the sludges from W24, W25, and W28 per the FWENC protocol. Pictures of the final treated waste forms for the five MVST samples are shown in Figs. 3.9, 3.10, 3.11 .

\subsubsection{Simple Drying of W24, W25, and W28 sludges}

Per the FWENC process, the three rinsed sludges that passed a wet TCLP test (W24, W25, and W28) were vacuum dried and subjected to TCLP testing again. These dried samples all passed EPA RCRA metals limits but did not meet UTS limits in mercury. Wet samples had previously failed UTS limits in both mercury and cadmium. Mercury levels in the TCLP extracts were measured to be (for triplicate, averaged samples) $0.031,0.037$, and $0.053 \mathrm{mg} / \mathrm{L}$ for W24, W25, and W28 respectively, which exceed the UTS limit of $0.025 \mathrm{mg} / \mathrm{L}$.

\subsubsection{Application of 'Optimum' Process to W26 and W27 Sludges}

The two worst-failing tank sludges, W26 and W27, were selected for treatment using the FWENC 'Optimum' process. This required that rinsed sludge samples from both tanks be subjected to a sequence of stabilizer additions followed by vacuum drying. Both of these sludges, even after treatment, continued to fail TCLP limits on mercury. For Tank W26, the wet TCLP extract level of mercury was measured to be $0.503 \mathrm{mg} / \mathrm{L}$ while the dry, treated extract levels (performed in triplicate) were $0.376 \pm 0.038,0.449 \pm$ 0.045 , and $0.071 \pm 0.007 \mathrm{mg} / \mathrm{L}$. The average of the dry, treated extracts was $0.299 \mathrm{mg} / \mathrm{L}$, which exceeds 
the EPA RCRA limit of $0.2 \mathrm{mg} / \mathrm{L}$. For W27, the wet TCLP extract level of mercury was measured to be $0.626 \mathrm{mg} / \mathrm{L}$ while the dry, treated extract levels (performed in triplicate) were $0.762 \pm 0.076,0.329 \pm$ 0.033 , and $0.468 \pm 0.047 \mathrm{mg} / \mathrm{L}$. The average of the dry, treated extracts was $0.520 \mathrm{mg} / \mathrm{L}$. In all other metals, both W26 and W26 treated sludge met EPA RCRA and UTS TCLP standards (prior to treatment, W26 sludge had also failed to meet UTS limits for cadmium).

\subsection{RESULTS FROM TESTING OF MVST ACTUAL TANK WASTE WASH/RINSE}

A concise description of rinse testing can be found immediately below. More detail and datasets can be found in Figs. 5.1 through 5.13.

\subsubsection{Results from MVST W24}

The sludge rinse was subjected to one TCLP test, which failed leach limits in cadmium. It should be noted that this sample was only dried and that stabilizers were NOT added. Cadmium, chromium, and mercury were all somewhat likely candidates to fail from theoretical leach calculations; about $90 \%$ of the chromium leached after simple drying, whereas only $17 \%$ of the mercury leached. The measured value of leached cadmium was actually greater than the theoretical leach based on the rinse analysis--although this indicates experimental error, it is likely that most of the cadmium is leaching out.

\subsubsection{Results from MVST W25}

The sludge rinse was subjected to one TCLP test, which failed in both cadmium and chromium and reached $70 \%$ of the leach limit in mercury. The maximum theoretical leach of chromium was expected to be $4.84 \mathrm{ppm}$ (5.00 ppm is the limit), the maximum theoretical leach for cadmium was $1.194 \mathrm{ppm}(1.00$ $\mathrm{ppm}$ is the limit), and the maximum theoretical leach of mercury was $0.237 \mathrm{ppm}(0.200 \mathrm{ppm}$ is the limit). Note that NO chemical additives were added to the rinse during the drying process in this test.

\subsubsection{Results from MVST W26}

Two samples of the sludge rinse were subjected to the 'Modified Optimum' FWENC process; both of these samples failed mercury leach limits. Based on the maximum theoretical leach concentrations of cadmium, chromium, mercury, and lead, it appears that stabilizer addition has only a modest effect on the leachability of the dried, treated rinse wasteform.

\subsubsection{Results from MVST W27}

One sample of the sludge rinse was subjected to the 'Modified Optimum' process, and it failed TCLP in mercury. The rinse leach level of chromium reached $64 \%$ of the acceptable limit, indicating a possible future failure knowing the variability in TCLP testing. Approximately $75 \%$ of the chromium leached away during testing.

\subsubsection{Results from MVST W28}

The sludge rinse failed TCLP in mercury, but the failure was very 'close' $(0.204 \mathrm{ppm})$. The leached chromium concentration passed, but was $55 \%$ of the leach limit. Note that chemical stabilizers WERE added for this rinse test, but NOT the previous sludge tests. Only one TCLP test was performed.

\subsubsection{Results from MVST W31}

Although there are only limited data for W31, it appears likely that the FWENC process will be able to stabilize the sludge. The sludge rinse, however, is likely to fail in both chromium and mercury. No 
wash/rinse TCLP tests were performed on W31 samples.

\subsection{FWENC BASIS FOR NOT ADDING STABLIZING AGENTS TO THE WASH/RINSE}

FWENC representatives indicated that mercury levels in the MVST tank supernates were low enough such that 'Optimum' and 'Alternate' treatments would not be necessary based on the prior work of Bayne et al. (1997a). This report contains historic data for several waste tanks at ORR, including the MVST tanks, up to 1996. The addendum to the report (Bayne et al., 1997b), in particular, addresses physical and chemical characteristics of the liquid supernatants. Because the MVST tanks are part of an active waste system, the report indicates that the values examined have varied widely from year to year. Discussions with one of the report's authors (A. B. Walker) indicated that current tank supernatant concentrations are likely to be very different from numbers listed in the report, and potentially much higher due to concentration efforts. Also, 'unlike the sludge, the supernatants in all tanks were produced from the same processes, were treated by the same evaporation process, and have been mixed between some tanks freely.'

By selecting the most recent (1996) data for the supernatants, which may be highly inaccurate, Table 5.2 was generated for the MVST supernatants present at that time, indicating supernatant mercury levels and their potential leachability (i.e., the mercury concentration resulting if this liquid waste was dried and all the mercury was subsequently extracted by TCLP).

When considering the rinse water from the sludge treatment process (a 5:1 volume ratio of added water) as applied to samples received during FY00, analytical results yielded the results shown in Table 5.3. This analysis assumed a good separation of solids from wash/rinse during the rinse process; and that Total Dissolved Solids were very close to the Total Solids Measurement for supernate.

A key factor that will be involved in actual supernatant processing will be the ratio of rinse water generated from sludge washing to the supernatant currently stored in the tanks. If the rinse water dominates the overall mass fraction of supernatant, chemical stabilization of the supernatants will likely be required. Additional characterization data for the supernates currently present in the tanks would enable a more accurate prediction of potential pass/failure. Another key factor is the accuracy of the total dissolved solids values that FWENC have used for their calculations and how representative they will be for the consolidated sludge/supernate currently stored in MVST for FWENC treatment. A lot of water was used to mobilize sludges to MVST, which may also confuse the issue. However, this should not change the total mass of solids contained in these tanks, although it could influence the distribution of RCRA metals between the separate sludge and liquid processing streams. 


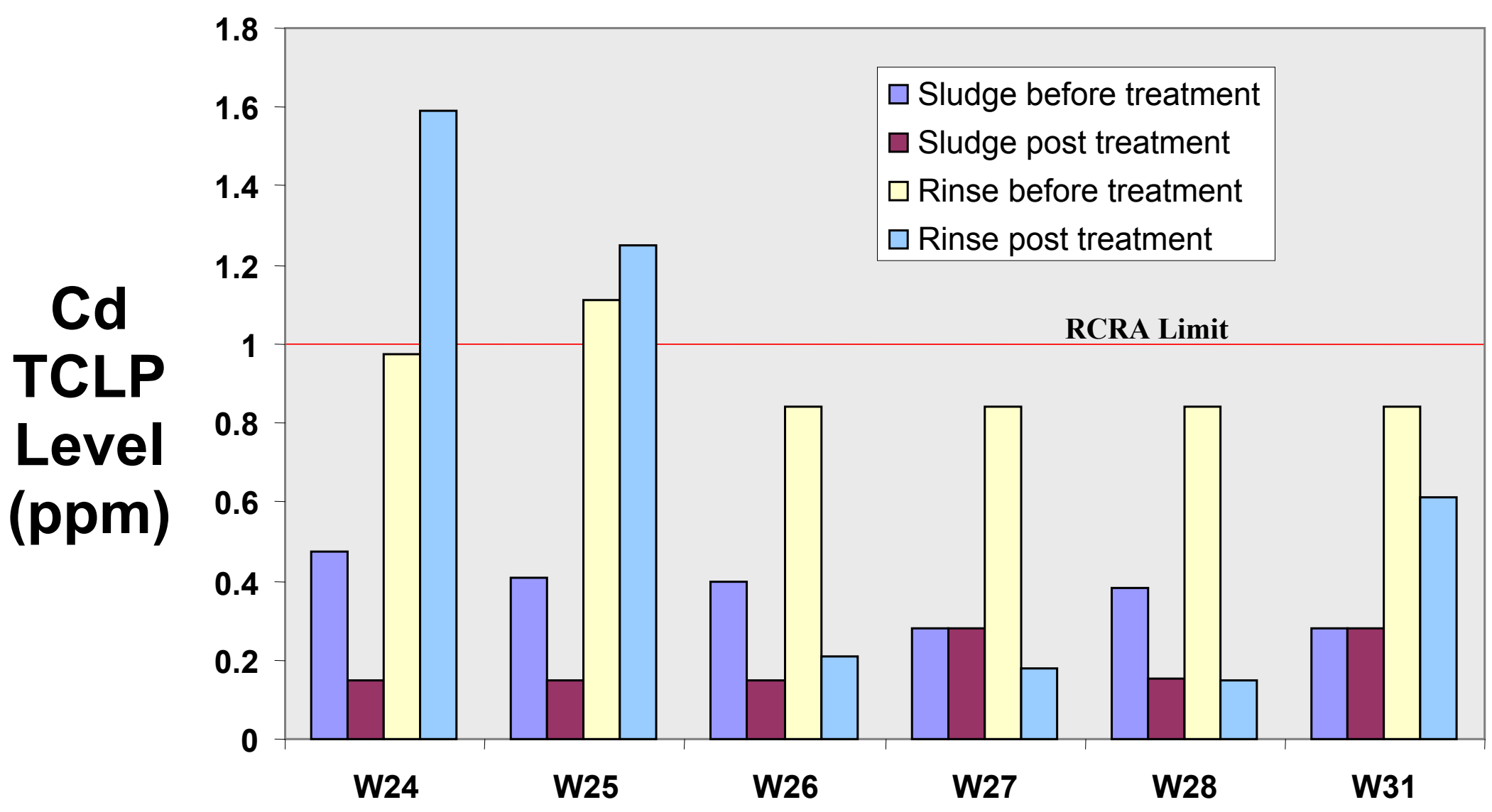

Fig. 5.1. TCLP leach values for cadmium in MVST tanks. RCRA TCLP limit for cadmium is $1 \mathrm{ppm}$. FWENC-treated sludges passed the test easily, but two supernate/rinses from those same tanks failed. The rinses from tanks W24 and W25 which failed in cadmium were subjected to the FWENC drying process without stabilizer addition; rinses from tanks W26, W27, and W28 had stabilizer addition. Data for Tank W31 are projected based on characterization data. 


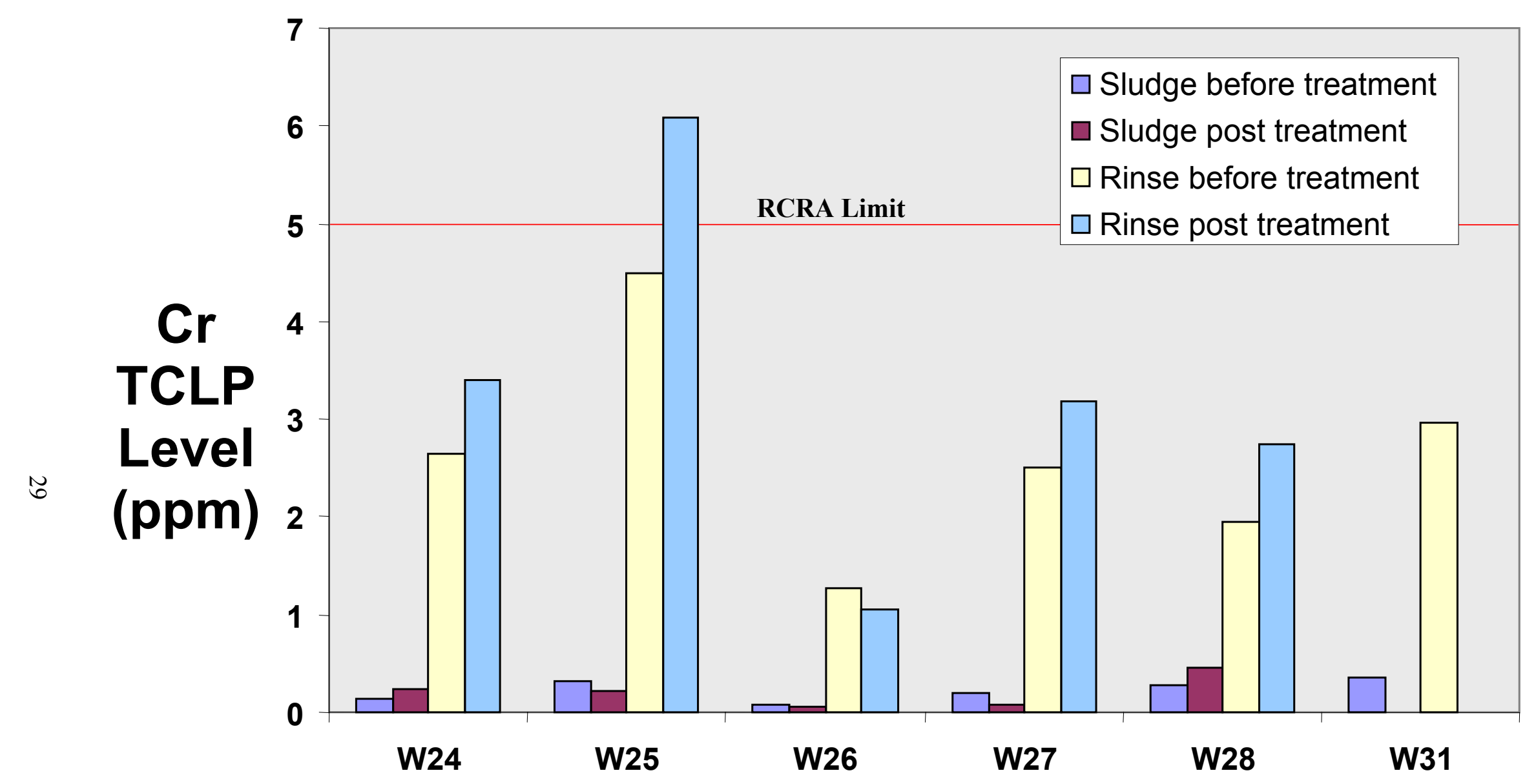

Fig. 5.2. TCLP leach values for chromium in MVST tanks. The RCRA TCLP limit for chromium is 5 ppm. FWENC-treated sludges passed the test easily, while wash/rinses from those same tanks come much closer to failure. Tank W25 actually failed for its wash/rinses - rinses from Tanks W24 and W25 were processed without stabilizer addition. 


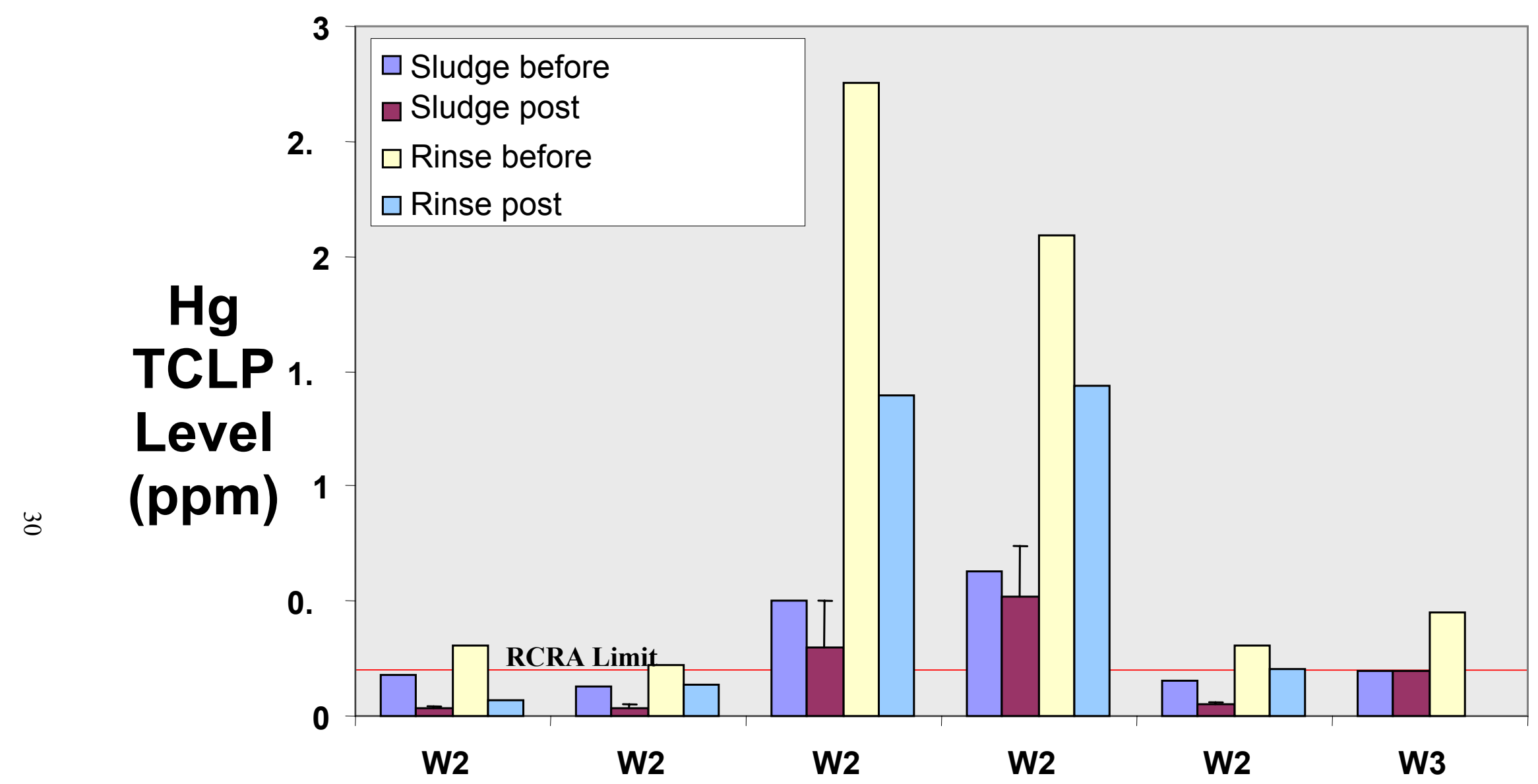

Fig. 5.3. TCLP leach values for mercury in MVST tanks. The RCRA TCLP limit for mercury is 0.2 ppm. Two of the FWENCtreated sludges failed TCLP, while four of the wash/rinses failed. Error bars represent one full deviation from the average of three replicates. Data for Tank W31 are projected based on characterization data. 


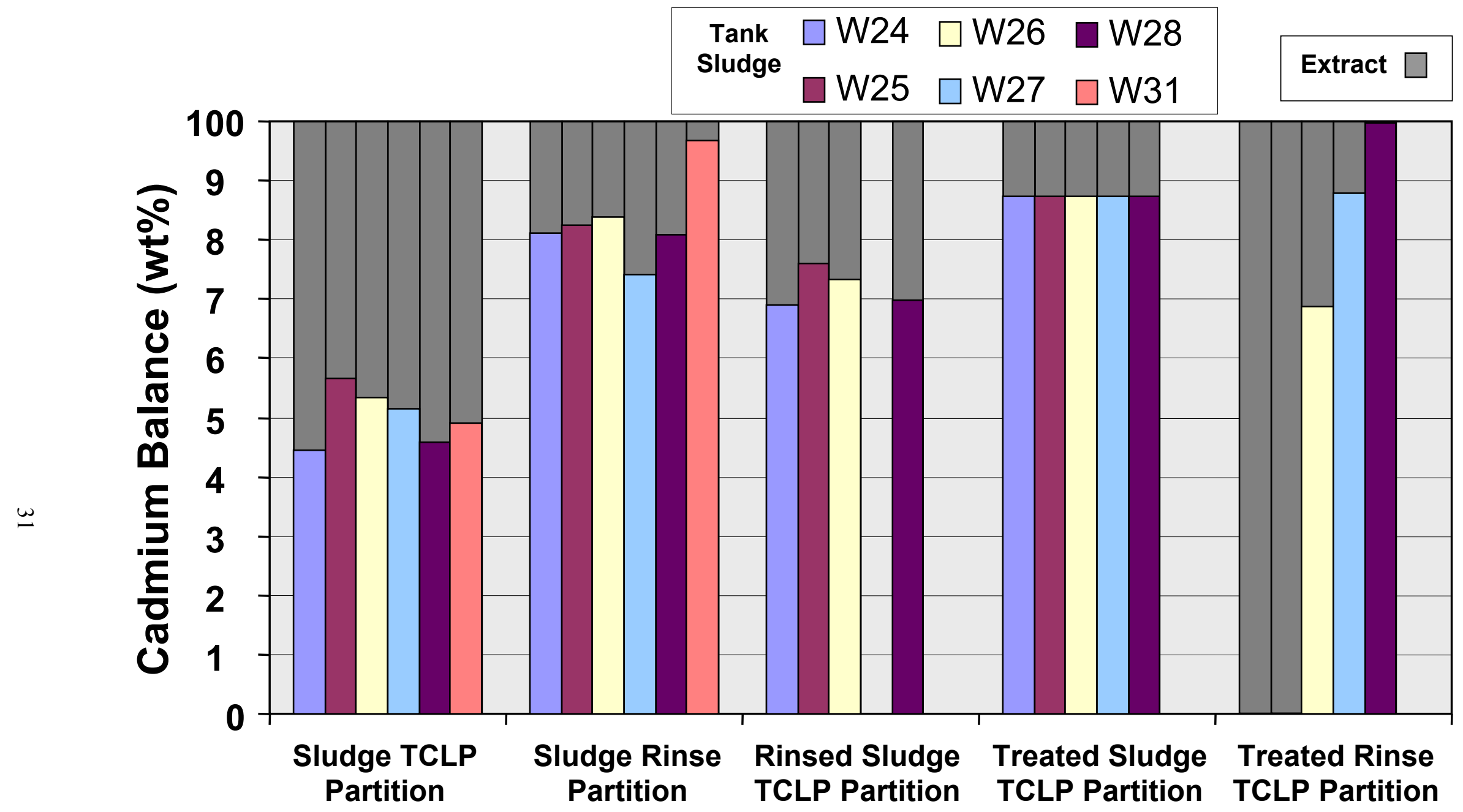

Fig. 5.4. Distribution between solid and liquid for TCLP extractions and sludge rinsing before and after treatment. The first set of bars denoted as 'Sludge TCLP Partition' are calculated estimates, based on TCLP values from the rinsed sludge and characterization data. They indicate that approximately half of the cadmium in the raw, untreated sludge would extract during a 'wet' TCLP test. Simple rinsing of raw sludge per the FWENC procedure removes about 20\% of the cadmium (Sludge-Rinse Partition). A TCLP analysis of wet, rinsed sludges (Rinsed Sludge TCLP Partition) indicates that $30 \%$ of the remaining cadmium will leach out; treated sludge is somewhat stabilized by the FWENC process--sludge phase values represented under 'Treated Sludge TCLP Partition' are minimum values for the amount of cadmium that remains unleachable during TCLP. The rinse water treatment results ranged from complete cadmium release to complete stabilization - this is thought to be due to the treatment method differences between Tanks W24, W25 and Tanks W26, W27, W28. Rinse samples from Tanks W24 and W25 were subject to FWENC evaporation without stabilizer addition. 


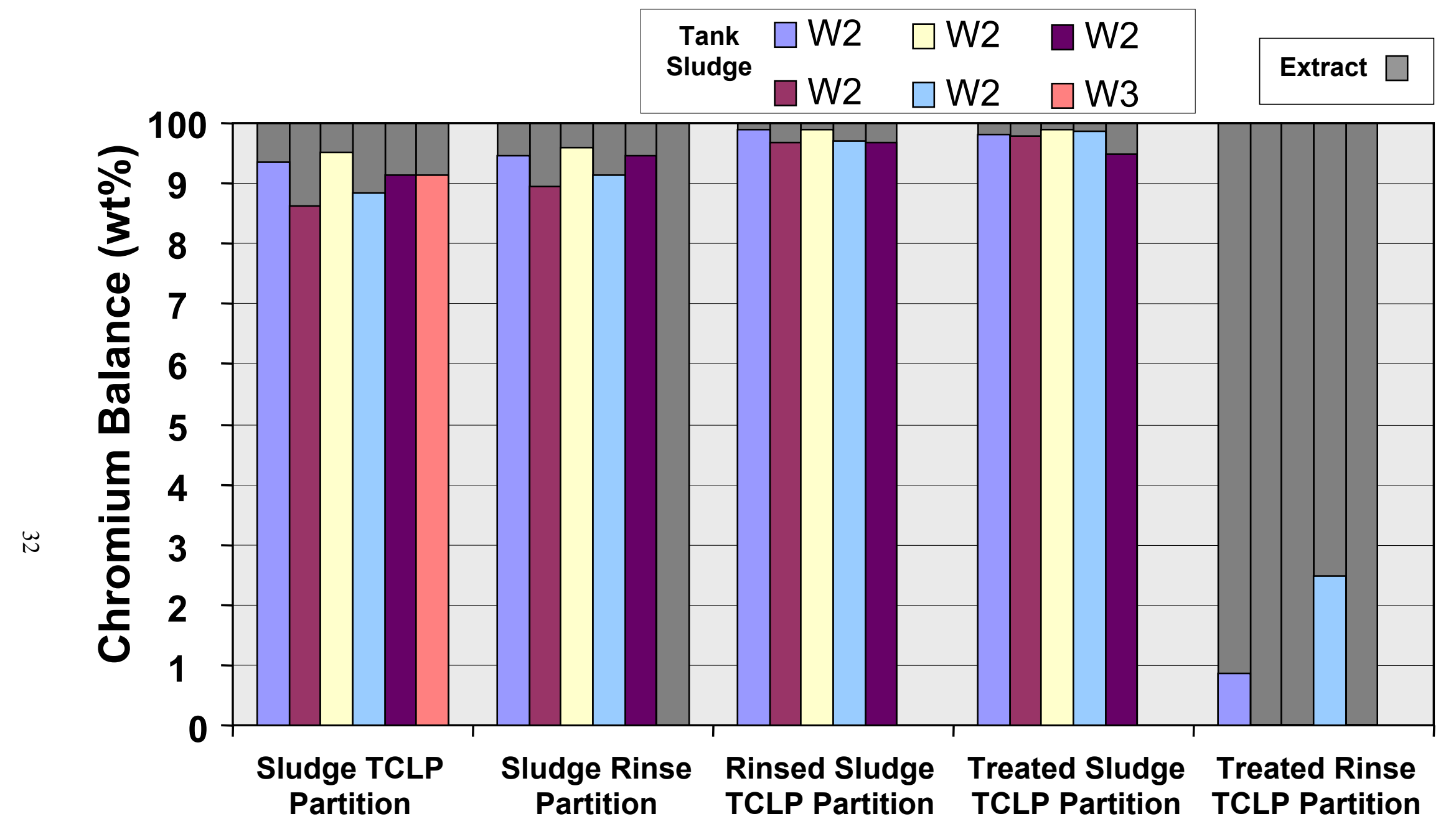

Fig. 5.5. Distribution of chromium between solid and liquid for TCLP extractions and sludge rinsing before and after treatment. The first set of bars denoted as 'Sludge TCLP Partition' includes calculated estimates, based on TCLP values from the rinsed sludge and characterization data. They indicate that approximately ten percent of the chromium in the raw, untreated sludge would extract during a 'wet' TCLP test. Simple rinsing of raw sludge per the FWENC procedure removes about $10 \%$ of the chromium as well (Sludge Rinse Partition), indicating that most of the chromium is not in a very soluble form. A TCLP analysis of wet, rinsed sludges (Rinsed Sludge TCLP Partition) indicates that very little of the remaining chromium will leach out; although leaching was very low for chromium during tests of the "Treated Sludge', the FWENC process did not enhance chromium stabilization versus the wet, rinsed sludge. The rinse water treatment results indicated large or nearly complete chromium release for the tank rinses tested—stabilizer addition does not appear to impact the TCLP leach values for chromium. 


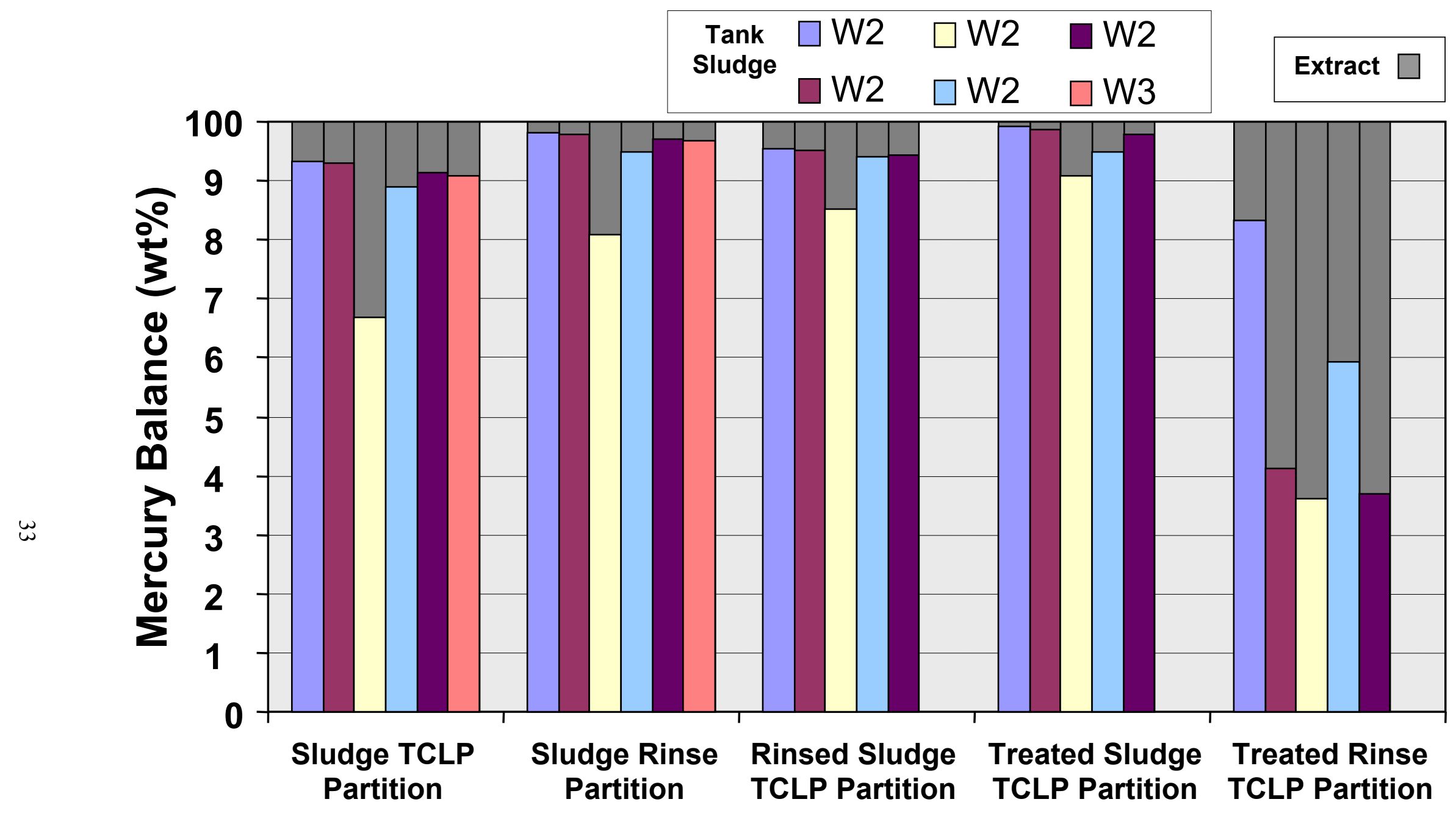

Fig. 5.6. Distribution of mercury between solid and liquid for TCLP extractions and sludge rinsing before and after treatment. The first set of bars denoted as 'Sludge TCLP Partition' are calculated estimates, based on TCLP values from the rinsed sludge and characterization data. They indicate that approximately ten percent of the mercury in the raw, untreated sludge would extract during a 'wet' TCLP test. Simple rinsing of raw sludge per the FWENC procedure removes about 5\% of the mercury as well (Sludge Rinse Partition), indicating that most of the mercury is not in a soluble form. A TCLP analysis of wet, rinsed sludges (Rinsed Sludge TCLP Partition) indicates that, on a percentage basis, very little of the remaining mercury will leach out; stabilization of the "Treated Sludge' does not appear to be much better after the FWENC process, although less mercury leaches during TCLP. The rinse water treatment results indicated that a very large portion, approaching 50\%, of the mercury in treated rinse water is released during a TCLP test—stabilizer addition does not appear to impact the TCLP leach values for mercury in the rinse waste form. 
Cells that have a fill color of dark grey indicate TCLP leach limit failure

Cells that have a fill color of light grey indicate TCLP concentrations that pass, but are within $50 \%$ of the leach limit.

\begin{tabular}{|c|c|c|c|c|c|c|c|c|}
\hline \multicolumn{9}{|c|}{ BVEST Tank W23 } \\
\hline \multirow[t]{2}{*}{ W23 } & Sludge Analysis & \multicolumn{3}{|c|}{ Sludge TCLP (mg/L) } & $\begin{array}{c}\text { Rinse } \\
\text { Analysis }\end{array}$ & \multicolumn{3}{|c|}{ Rinse TCLP (mg/L) } \\
\hline & $1996(\mathrm{mg} / \mathrm{kg})$ & Drying Only 1 & Drying Only 1 & Drying Only 1 & (mg/L) & \begin{tabular}{c|} 
Maximum \\
Theoretical \\
Leach
\end{tabular} & $\begin{array}{c}\text { After Drying } \\
\text { Only }\end{array}$ & \begin{tabular}{|l} 
FWENC \\
Additives \\
\& Drying
\end{tabular} \\
\hline $\begin{array}{l}\mathrm{Cd} \\
\mathrm{Cr} \\
\mathrm{Hg} \\
\mathrm{Pb}\end{array}$ & $\begin{array}{c}24 \\
161 \\
35 \\
705\end{array}$ & $\begin{array}{c}0.205 \\
0.0551 \\
<0.00835 \\
0.325\end{array}$ & $\begin{array}{c}0.172 \\
<0.015 \\
<0.00835 \\
0.38\end{array}$ & $\begin{array}{c}0.289 \\
0.237 \\
<0.00835 \\
0.474\end{array}$ & $\begin{array}{c}\text { Not } \\
\text { Performed }\end{array}$ & & \begin{tabular}{|c|}
0.665 \\
1.94 \\
0.0124 \\
1.44 \\
\end{tabular} & $\begin{array}{c}0.349 \\
0.0685 \\
<0.00835 \\
1.21\end{array}$ \\
\hline
\end{tabular}

Total Solids:

$(\mathrm{mg} / \mathrm{g})$

62.1

Comments. All three sludge samples, after simple drying, passed TCLP. With the exception of cadmium, no RCRA metal concentrations came within $10 \%$ of the leach limits.

Cadmium reached $29 \%$ of the leach limit in the sludge samples. Cadmium reached $66 \%$ of the leach limit in the sludge rinse when subjected to simple drying; this level

dropped to $35 \%$ after chemical additives were applied. When the FWENC additives were added to the rinse (using the 'Modified' process), decreased leach levels of cadmium

(by $48 \%$ ), chromium (96\%), mercury (nearly $100 \%$ ), and lead (16\%) were observed. Note that two tests were run on the rinse: one involved simple drying while the other

involved addition of chemical stabilizers per the 'Modified Optimum' process.

Result. The FWENC process stabilizes both sludge and the wash/rinse.

Fig. 5.7. Results from BVEST W23 
Cells that have a fill color of dark grey indicate TCLP leach limit failure

Cells that have a fill color of light grey indicate TCLP concentrations that pass, but are within $50 \%$ of the leach limit.

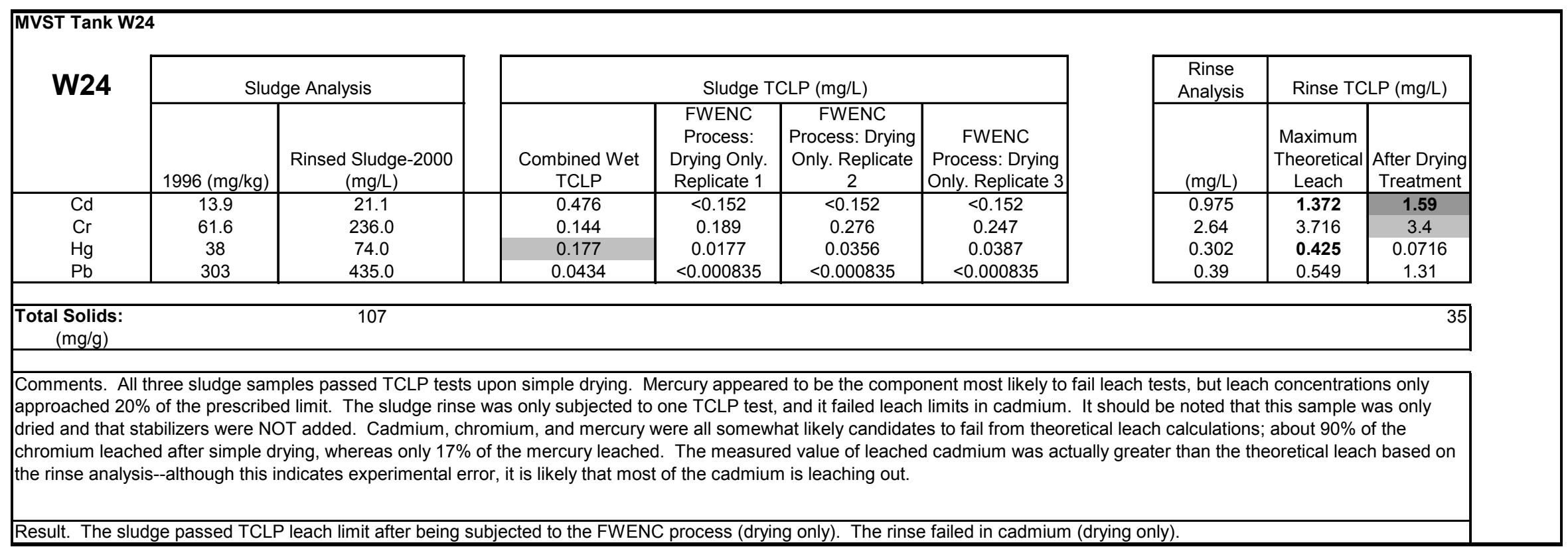

\begin{tabular}{|c|c|c|c|c|c|c|}
\hline \multicolumn{7}{|c|}{ Where is the mass going? } \\
\hline & $\begin{array}{c}\text { Initial Con- } \\
\text { centration } \\
\text { Sludge }(\mathrm{mg} / \mathrm{L})\end{array}$ & Rinse Analysis (mg/L) & $\begin{array}{l}\text { Percent of } \\
\text { Original Mass that } \\
\text { becomes part of } \\
\text { Rinse }\end{array}$ & $\begin{array}{l}\text { Percent that } \\
\text { leaches from } \\
\text { Sludge (wet } \\
\text { TCLP) }\end{array}$ & \begin{tabular}{|l|} 
Percent that \\
leaches from \\
Dried Sludge \\
(Average of \\
FWENC Drying \\
replicates
\end{tabular} & $\begin{array}{l}\text { Percent that } \\
\text { leaches from } \\
\text { Dried } \\
\text { Wash/Rinse }\end{array}$ \\
\hline \multirow{4}{*}{$\begin{array}{l}\mathrm{Cd} \\
\mathrm{Cr} \\
\mathrm{Hg} \\
\mathrm{Pb}\end{array}$} & 21.1 & 0.975 & 18.77 & 31.09 & $<12.59$ & 115.87 \\
\hline & 236.0 & 2.64 & 5.30 & 1.21 & 1.97 & 91.50 \\
\hline & 74.0 & 0.302 & 2.00 & 4.57 & 0.82 & 16.84 \\
\hline & 435.0 & 0.39 & 0.45 & 0.20 & $<0.00$ & 238.66 \\
\hline
\end{tabular}

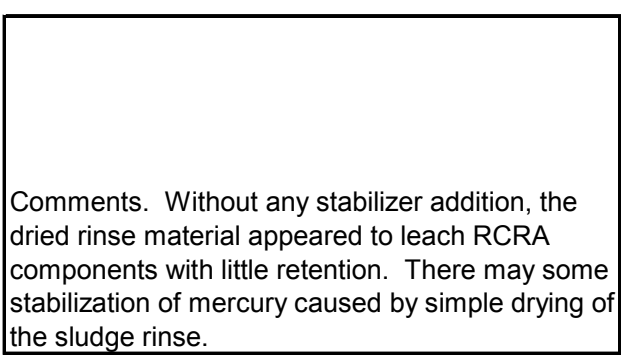

Fig. 5.8. Results from MVST 24 
Cells that have a fill color of dark grey indicate TCLP leach limit failure

Cells that have a fill color of light grey indicate TCLP concentrations that pass, but are within $50 \%$ of the leach limit.

\begin{tabular}{|c|c|c|c|c|c|c|c|c|c|}
\hline \multicolumn{3}{|c|}{ MVST Tank W25 } & & & & & & & \\
\hline \multirow[t]{2}{*}{ W25 } & \multicolumn{2}{|c|}{ Sludge Analysis } & \multicolumn{4}{|c|}{ Sludge TCLP $(\mathrm{mg} / \mathrm{L})$} & $\begin{array}{c}\text { Rinse } \\
\text { Analysis } \\
\end{array}$ & \multicolumn{2}{|c|}{ Rinse TCLP (mg/L) } \\
\hline & $1996(\mathrm{mg} / \mathrm{kg})$ & $\begin{array}{l}\text { Rinsed Sludge-2000 } \\
(\mathrm{mg} / \mathrm{L})\end{array}$ & $\begin{array}{l}\text { Combined Wet } \\
\text { TCLP }\end{array}$ & $\begin{array}{l}\text { FWENC } \\
\text { Process: } \\
\text { Drying Only. } \\
\text { Replicate } 1\end{array}$ & \begin{tabular}{|l|} 
FWENC \\
Process: Drying \\
Only. Replicate \\
2
\end{tabular} & \begin{tabular}{|l|} 
FWENC \\
Process: Drying \\
Only. Replicate 3 \\
\end{tabular} & $(\mathrm{mg} / \mathrm{L})$ & $\begin{array}{c}\text { Maximum } \\
\text { Theoretical } \\
\text { Leach }\end{array}$ & $\begin{array}{l}\text { After Drying } \\
\text { Treatment }\end{array}$ \\
\hline $\mathrm{Cd}$ & 11.9 & 26.0 & 0.409 & $<0.152$ & \begin{tabular}{l|}
$<0.152$ \\
\end{tabular} & $<0.152$ & 1.11 & 1.194 & 1.25 \\
\hline $\mathrm{Cr}$ & 92.1 & 190.0 & 0.327 & 0.235 & 0.202 & 0.215 & 4.5 & 4.840 & 6.09 \\
\hline $\mathrm{Hg}$ & 73.2 & 49.1 & 0.127 & 0.0346 & 0.0277 & 0.0483 & 0.22 & 0.237 & 0.139 \\
\hline $\mathrm{Pb}$ & 442 & 454.0 & 0.0391 & $<0.000835$ & $<0.000835$ & $<0.000835$ & 0.508 & 0.546 & $<0.519$ \\
\hline \multicolumn{7}{|c|}{$\begin{array}{|cc|}\begin{array}{c}\text { Total Solids: } \\
(\mathrm{mg} / \mathrm{g})\end{array} & 124 \\
\end{array}$} & & & 45.8 \\
\hline \multicolumn{10}{|c|}{$\begin{array}{l}\text { Comments. Three sludge samples passed TCLP testing under the 'wet' test and also upon simple drying. Mercury appeared to be the component most likely to fail in the sludge } \\
\text { TCLP tests; actual leach values did not reach } 25 \% \text { of the leach limit. The sludge rinse failed in both cadmium and chromium and reached } 70 \% \text { of the leach limit in mercury. The } \\
\text { maximum theoretical leach of chromium was expected to be } 4.84 \mathrm{ppm} \text { ( } 5.00 \mathrm{ppm} \text { is the limit), the maximum theoretical leach for cadmium was } 1.194 \mathrm{ppm}(1.00 \mathrm{ppm} \text { is the limit), and } \\
\text { the maximum theoretical leach of mercury was } 0.237 \mathrm{ppm}(0.200 \mathrm{ppm} \text { is the limit). Note that no chemical additives were added to the rinse during the drying process in this test. }\end{array}$} \\
\hline
\end{tabular}

\begin{tabular}{|c|c|c|c|c|c|c|}
\hline \multicolumn{7}{|c|}{ Where is the mass going? } \\
\hline & $\begin{array}{c}\text { Initial Concen } \\
\text { tration in } \\
\text { Sludge (mg/L) }\end{array}$ & $\begin{array}{c}\text { Rinse Analysis } \\
(\mathrm{mg} / \mathrm{L})\end{array}$ & $\begin{array}{l}\text { Percent of } \\
\text { Original Mass } \\
\text { that becomes } \\
\text { part of Rinse }\end{array}$ & $\begin{array}{c}\text { Percent that } \\
\text { leaches from } \\
\text { Sludge (wet } \\
\text { TCLP) }\end{array}$ & $\begin{array}{c}\text { Percent that } \\
\text { leaches from } \\
\text { Dried Sludge } \\
\text { (Average of } \\
\text { FWENC Drying } \\
\text { replicates }\end{array}$ & $\begin{array}{c}\text { Percent that } \\
\text { leaches from } \\
\text { Dried } \\
\text { Wash/Rinse }\end{array}$ \\
\hline Cd & 26.0 & 1.1 & 17.59 & 23.93 & $<12.59$ & 104.70 \\
\hline $\mathrm{Cr}$ & 190.0 & 4.5 & 10.59 & 3.33 & 2.24 & 125.82 \\
\hline $\mathrm{Hg}$ & 49.1 & 0.2 & 2.19 & 4.92 & 1.48 & 58.74 \\
\hline $\mathbf{P b}$ & 454.0 & 0.5 & 0.56 & 0.17 & $<0.00$ & $<95.05$ \\
\hline
\end{tabular}

Comments. Without any stabilizer addition, the dried rinse material appears to leach its RCRA components with little retention.

Fig. 5.9. Results from MVST W25 


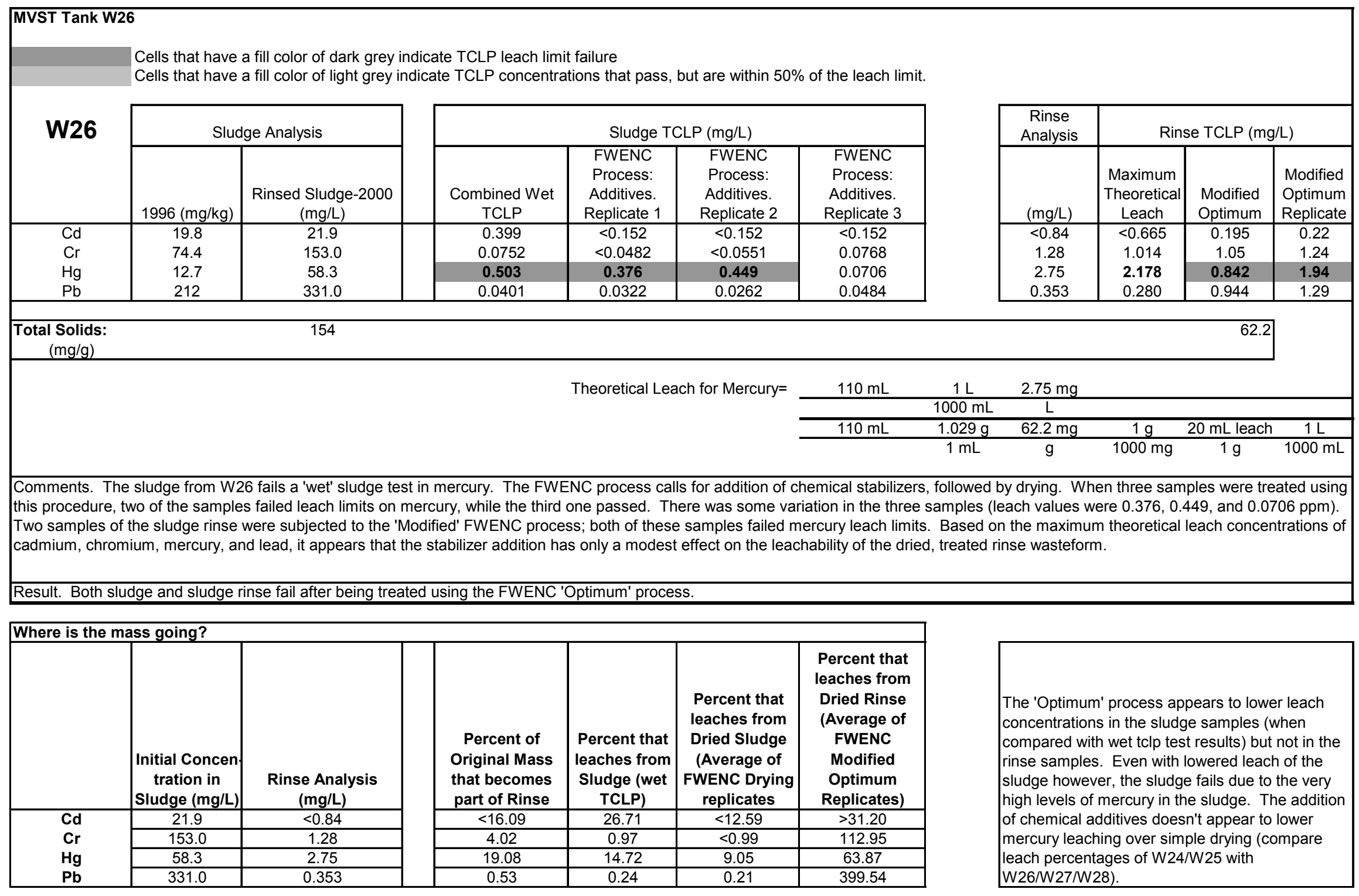

Fig. 5.10. Results from MVST W26 


\begin{tabular}{|c|c|c|c|c|c|c|c|c|c|}
\hline \multicolumn{10}{|c|}{ MVST Tank W27 } \\
\hline \multirow{3}{*}{ W27 } & \multicolumn{6}{|c|}{$\begin{array}{l}\text { Cells that have a fill color of dark grey indicate TCLP leach limit failure } \\
\text { Cells that have a fill color of light grey indicate TCLP concentrations that pass, but are within } 50 \% \text { of the leach limit. }\end{array}$} & & & \\
\hline & \multicolumn{2}{|c|}{ Sludge Analysis } & \multicolumn{4}{|c|}{ Sludge TCLP (mg/L) } & $\begin{array}{c}\text { Rinse } \\
\text { Analysis }\end{array}$ & \multicolumn{2}{|c|}{ Rinse TCLP (mg/L) } \\
\hline & $1996(\mathrm{mg} / \mathrm{kg})$ & $\begin{array}{l}\text { Rinsed Sludge-2000 } \\
(\mathrm{mg} / \mathrm{L})\end{array}$ & $\begin{array}{l}\text { Combined Wet } \\
\text { TCLP }\end{array}$ & $\begin{array}{l}\text { FWENC } \\
\text { Process: } \\
\text { Additives. } \\
\text { Replicate } 1\end{array}$ & $\begin{array}{l}\text { FWENC } \\
\text { Process: } \\
\text { Additives. } \\
\text { Replicate } 2 \\
\end{array}$ & $\begin{array}{l}\text { FWENC } \\
\text { Process: } \\
\text { Additives. } \\
\text { Replicate } 3\end{array}$ & $(\mathrm{mg} / \mathrm{L})$ & $\begin{array}{c}\text { Maximum } \\
\text { Theoretical } \\
\text { Leach }\end{array}$ & $\begin{array}{l}\text { Modified } \\
\text { Optimum }\end{array}$ \\
\hline $\mathrm{Cd}$ & 14.8 & $<16$ & $<0.28$ & $<0.152$ & $<0.152$ & $<0.152$ & $<0.84$ & $<1.422$ & 0.177 \\
\hline $\mathrm{Cr}$ & 55.3 & 132.0 & 0.207 & 0.105 & 0.0685 & 0.0919 & 2.5 & 4.232 & 3.18 \\
\hline $\mathrm{Hg}$ & 29 & 196.0 & 0.626 & 0.762 & 0.329 & 0.468 & 2.09 & 3.538 & 1.44 \\
\hline $\mathrm{Pb}$ & 157 & 317.0 & 0.0361 & $<0.000835$ & 0.0191 & $<0.000835$ & 0.141 & 0.239 & $<0.519$ \\
\hline \multicolumn{7}{|c|}{$\left.\begin{array}{cc}\text { Total Solids: } \\
(\mathrm{mg} / \mathrm{g})\end{array}\right) 41.4$} & \multicolumn{3}{|r|}{29.1} \\
\hline \multicolumn{10}{|c|}{$\begin{array}{l}\text { Comments: The sludge fails a 'wet' TCLP test; three subsequent samples were subjected to the 'Optimum' process. All three samples failed to pass leach limits in mercury. The } \\
\text { sludge rinse was subjected to the 'Modified Optimum' process, and failed in mercury. The rinse leach level of chromium reached } 64 \% \text { of the acceptable limit, indicating a possible } \\
\text { future failure knowing the variability in TCLP testing. Approximately } 75 \% \text { of the chromium leached away during testing. }\end{array}$} \\
\hline
\end{tabular}

\begin{tabular}{|c|c|c|c|c|c|c|}
\hline \multicolumn{7}{|c|}{ Where is the mass going? } \\
\hline & $\begin{array}{c}\text { Initial Concen } \\
\text { tration in } \\
\text { Sludge }(\mathrm{mg} / \mathrm{L})\end{array}$ & $\begin{array}{l}\text { Rinse Analysis } \\
\text { (mg/L) }\end{array}$ & $\begin{array}{c}\text { Percent of } \\
\text { Original Mass } \\
\text { that becomes } \\
\text { part of Rinse }\end{array}$ & $\begin{array}{c}\text { Percent that } \\
\text { leaches from } \\
\text { Sludge (wet } \\
\text { TCLP) }\end{array}$ & $\begin{array}{c}\text { Percent that } \\
\text { leaches from } \\
\text { Dried Sludge } \\
\text { (Average of } \\
\text { FWENC } \\
\text { Process } \\
\text { replicates }\end{array}$ & $\begin{array}{l}\text { Percent that } \\
\text { leaches from } \\
\text { Dried, Treated } \\
\text { Supernate }\end{array}$ \\
\hline \multirow{4}{*}{$\begin{array}{l}\mathrm{Cd} \\
\mathrm{Cr} \\
\mathrm{Hg} \\
\mathrm{Pb}\end{array}$} & \begin{tabular}{|l|}
$<16.0$ \\
\end{tabular} & $<0.84$ & $<25.75$ & ND & $<12.59$ & $>12$ \\
\hline & 132.0 & 2.5 & 8.65 & 3.04 & 1.32 & 75.14 \\
\hline & 196.0 & 2.09 & 5.06 & 6.00 & 5.01 & 40.70 \\
\hline & 317.0 & 0.141 & 0.22 & 0.23 & $<0.04$ & $<217$ \\
\hline
\end{tabular}

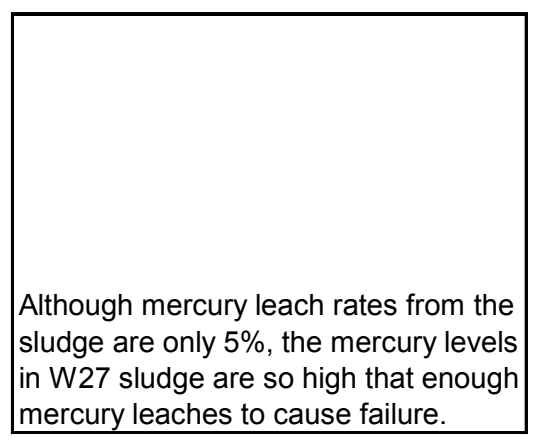

Fig. 5.11. Results from MVST W27 


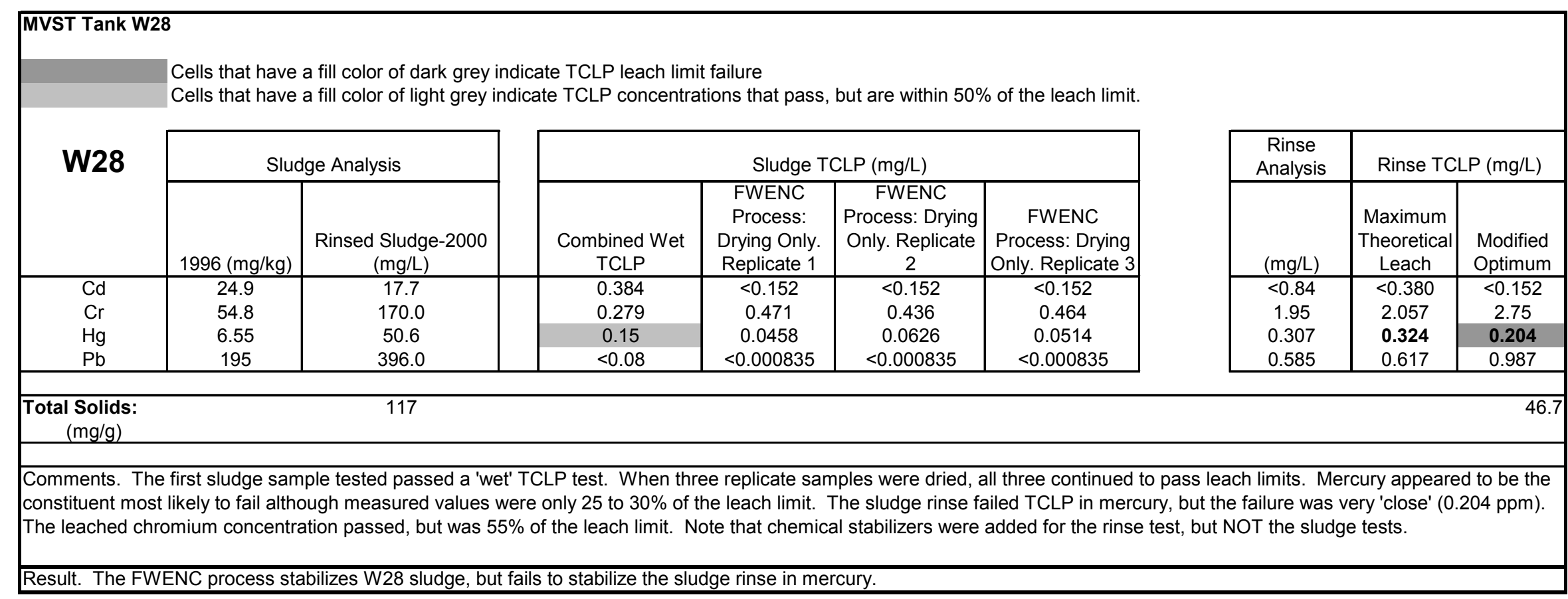

\begin{tabular}{|c|c|c|c|c|c|c|}
\hline \multicolumn{7}{|c|}{ Where is the mass going? } \\
\hline & $\begin{array}{c}\text { Initial Concen } \\
\text { tration in } \\
\text { Sludge }(\mathrm{mg} / \mathrm{L})\end{array}$ & $\begin{array}{c}\text { Rinse Analysis } \\
\text { (mg/L) }\end{array}$ & $\begin{array}{c}\text { Percent of } \\
\text { Original Mass } \\
\text { that becomes } \\
\text { part of Rinse }\end{array}$ & $\begin{array}{c}\text { Percent that } \\
\text { leaches from } \\
\text { Sludge (wet } \\
\text { TCLP) }\end{array}$ & $\begin{array}{c}\text { Percent that } \\
\text { leaches from } \\
\text { Dried Sludge } \\
\text { (Average of } \\
\text { FWENC Drying } \\
\text { replicates } \\
\end{array}$ & $\begin{array}{l}\text { Percent that } \\
\text { leaches from } \\
\text { Dried, Treated } \\
\text { Supernate } \\
\end{array}$ \\
\hline Cd & \begin{tabular}{|l|}
17.7 \\
\end{tabular} & 0.84 & $<19.18$ & 30.26 & $<12.59$ & $<0.40$ \\
\hline $\mathrm{Cr}$ & 170.0 & 1.95 & 5.42 & 3.18 & 5.10 & 133.69 \\
\hline $\mathrm{Hg}$ & 50.6 & 0.31 & 2.94 & 5.60 & 2.06 & 62.99 \\
\hline $\mathbf{P b}$ & 396.0 & 0.59 & 0.73 & $<0.40$ & $<0.00$ & 159.95 \\
\hline
\end{tabular}

\begin{tabular}{|l|}
\hline \\
Simple drying of the sludge increases \\
retention of mercury in the sludge \\
samples (when compared with wet \\
sludge). The sludge rinse however \\
leaches considerably even after \\
chemical stabilizers are added.
\end{tabular}

Fig. 5.12. Results from MVST W28 


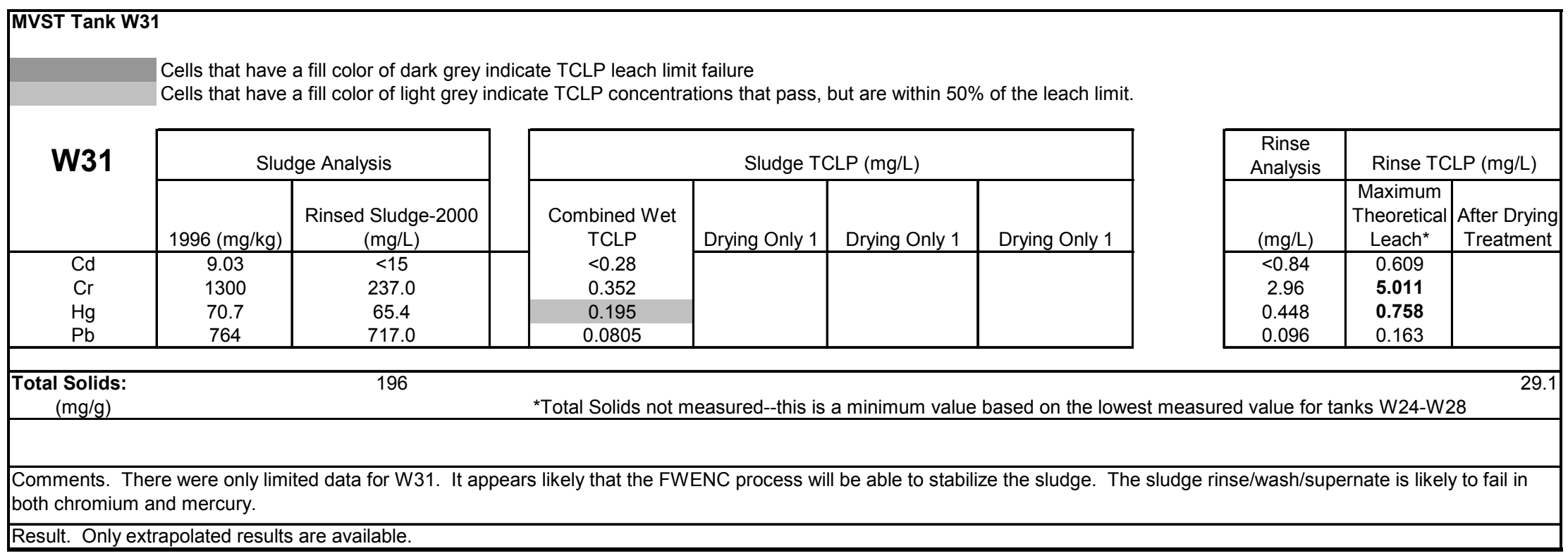

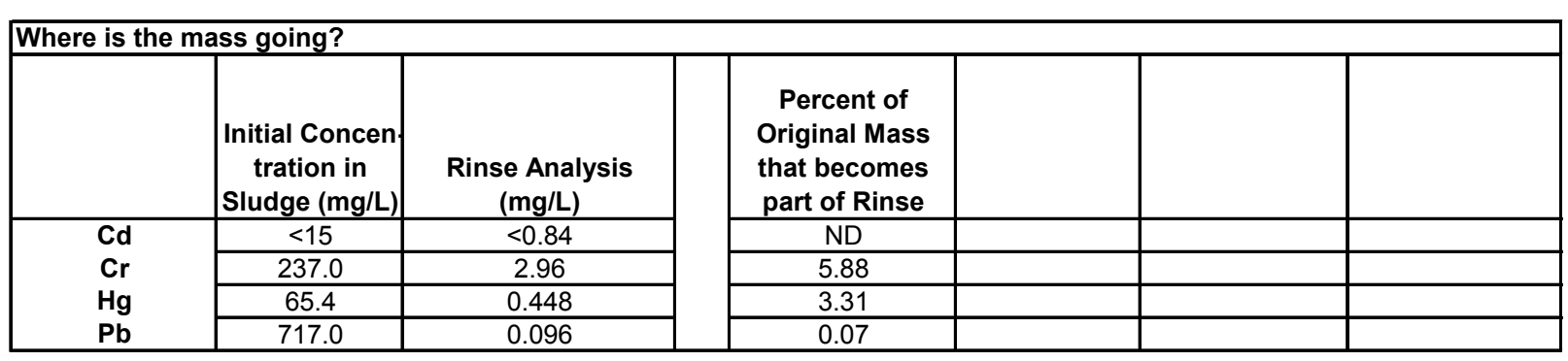

Fig. 5.13. Results from MVST W31. Sparse data were available and prevent a full analysis. 
Table 5.1. Matrix of MVST tanks and pass/fail results from a wet TCLP of the sludge (after wash) and the wash/rinse itself (based on ionic concentrations/simulated evaporation/TCLP).

\begin{tabular}{ccc}
\hline MVST tank & Wet TCLP & Wash/rinse \\
\hline W-24 & Pass & Fail \\
W-25 & Pass & Fail \\
W-26 & Fail & Fail \\
W-27 & Fail & Fail \\
W-28 & Pass & Fail \\
W-31 & Fail & Fail \\
\hline
\end{tabular}

Table 5.2. Pass/fail estimates based on 1996 measurements of MVST supernatants (Bayne et al, 1997). All but one of the MVST supernatants would pass TCLP. The RCRA leach limit on mercury is $0.2 \mathrm{ppm}$.

\begin{tabular}{cccc}
\hline MVST tank & $\begin{array}{c}\text { Mercury concentration in } \\
\text { actual supernate }(\mathrm{ppm})\end{array}$ & $\begin{array}{c}\text { Total solids } \\
\text { measurement (ppm) }\end{array}$ & $\begin{array}{c}\text { Theoretical TCLP } \\
\text { mercury leach } \\
\text { concentration (ppm) }\end{array}$ \\
\hline W24 & 0.1 & 320 & 0.016 \\
W25 & 0.1 & 360 & 0.014 \\
W26 & 0.9 & 430 & 0.105 \\
W27 & 0.3 & 390 & 0.038 \\
W28 & 0.2 & 580 & 0.017 \\
W31 & 2.3 & 440 & $\mathbf{0 . 2 6 1}$ \\
\hline
\end{tabular}

Table 5.3. Pass/fail estimates based on 2000 measurements of MVST sludges; data indicate that at least three of the tanks (W26, W27, and W31) could fail. The remaining tanks were close to failure. The RCRA leach limit on mercury is $0.2 \mathrm{ppm}$.

\begin{tabular}{cccc}
\hline MVST tank & $\begin{array}{c}\text { Mercury concentration in } \\
\text { supernate }(\mathrm{ppm})\end{array}$ & $\begin{array}{c}\text { Total dissolved solids } \\
\text { measurement (ppm) }\end{array}$ & $\begin{array}{c}\text { Theoretical TCLP } \\
\text { mercury leach } \\
\text { concentration (ppm) }\end{array}$ \\
\hline W24 & $\mathbf{0 . 3 0 2}$ & 107 & 0.141 \\
W25 & $\mathbf{0 . 2 2 0}$ & 124 & 0.089 \\
W26 & $\mathbf{2 . 7 5 0}$ & $\mathbf{1 5 4}$ & $\mathbf{0 . 8 9 3}$ \\
W27 & $\mathbf{2 . 0 9 0}$ & $\mathbf{4 1 . 4}$ & $\mathbf{2 . 5 2 4}$ \\
W28 & $\mathbf{0 . 3 0 7}$ & 117 & 0.131 \\
W31 & $\mathbf{0 . 4 4 8}$ & $\mathbf{7 9 . 2}$ & $\mathbf{0 . 2 8 3}$ \\
\hline
\end{tabular}




\section{LONG TERM TESTING}

\subsection{BACKGROUND}

One objective of TTP OR0-0-WT-31, 3TKH, was to evaluate long-term performance of the Foster Wheeler Stabilization Process (in terms of TCLP performance). This was done in two ways using the W23S sludge surrogate: (1) free water affinity of the surrogate as a function of storage time and environmental condition, and (2) freeze-thaw thermal cycling.

\subsection{FREE WATER TEST RESULTS AFTER NINE MONTHS}

After nine months, samples that were stored under indoor ambient conditions showed no accumulation of free water and continued to pass TCLP. Similarly, samples that were stored in an unconditioned trailer (exposure to east Tennessee outdoor ambient conditions - see Fig. 6.1) accumulated no free water and continued to pass TCLP. Individual data are presented in Table 4.14.

\subsection{THERMAL DEGRADATION TESTING}

All W23S sludge surrogate replicates, after going through thermal cycling (see Fig. 6.2), showed no signs of free water accumulation and continued to pass TCLP tests. Only the stabilized sludge surrogate was tested (no wash/rinse solutions) since the treated wash/rinses did not consistently pass TCLP.

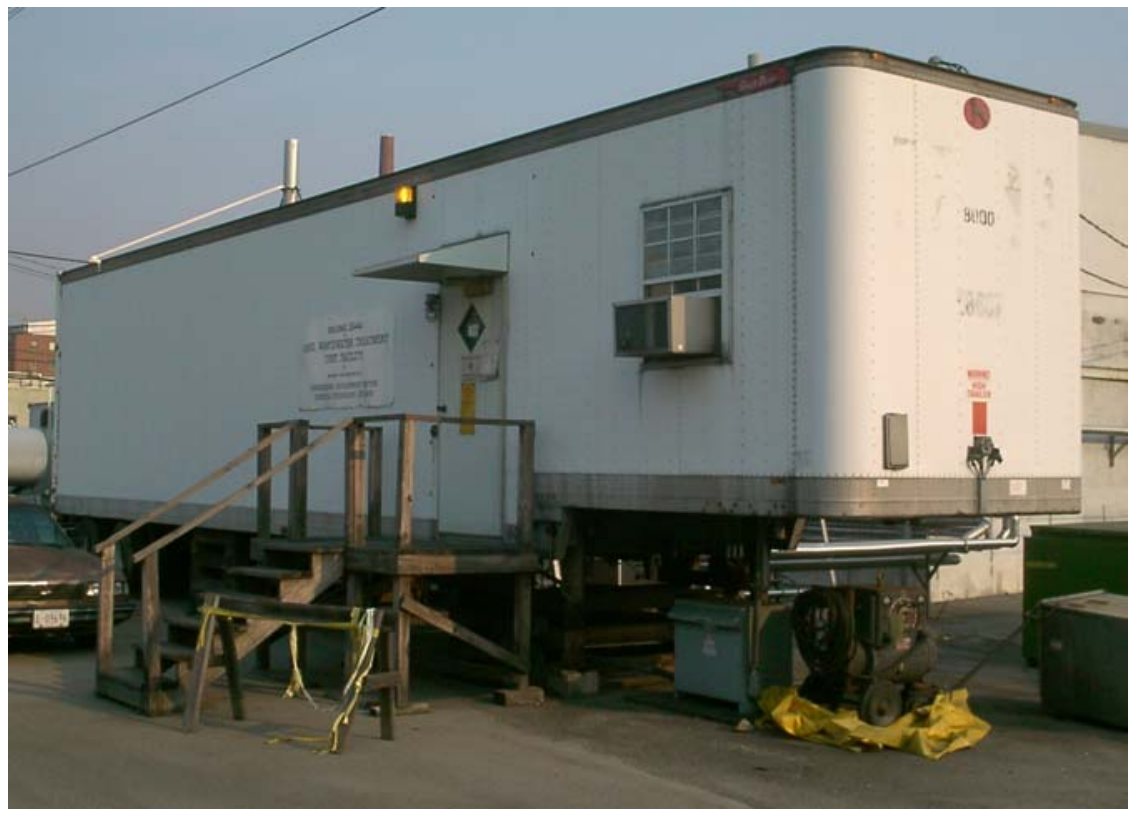

Fig. 6.1. Long term testing of surrogate sludge was conducted under ambient conditions within an unconditioned section of OR trailer. Samples were subjected to natural extremes of temperature and humidity over the course of 9 months. 


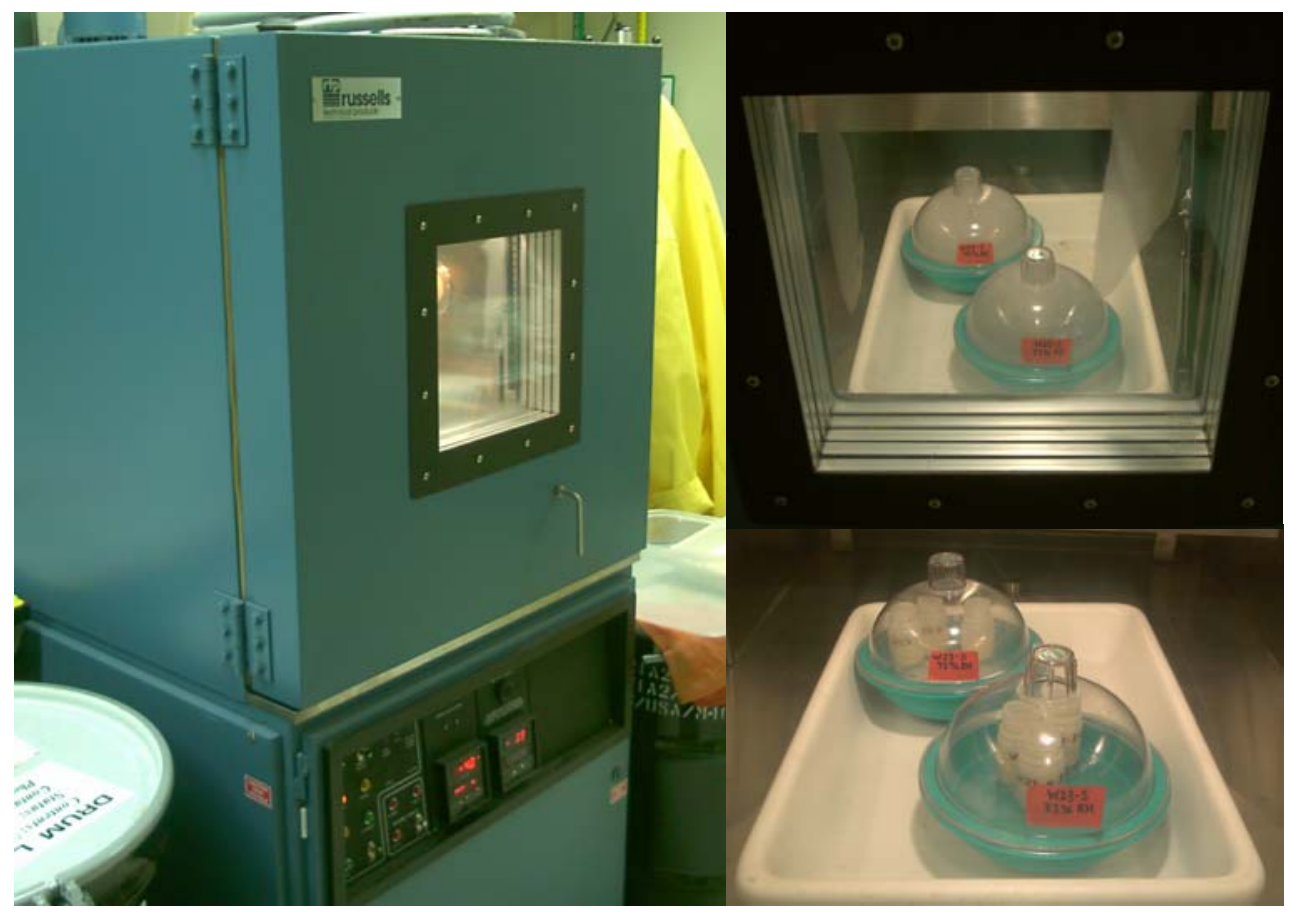

Fig. 6.2. Thermal cycler used to test durability of stabilized W23S surrogate sludge. Lightly capped samples were stored in controlled humidity chambers, and exposed to alternating extremes of heat and cold over for 30 cycles. 


\section{CONCLUSIONS}

The Foster Wheeler Environmental Corporation proposes to treat the Melton Valley Storage Tank (MVST) tank waste by:

(1) Separating the supernate from the sludge,

(2) Washing the sludge with water and adding this wash water to the supernate,

(3) Stabilizing the supernate/wash water or the washed sludge with additives if either are projected to fail Resource Conservation Recovery Act (RCRA) Toxic Characteristics Leaching Protocol (TCLP) criteria, and

(4) Stabilizing both the washed sludge and supernate/wash water by vacuum evaporation.

An independent laboratory evaluation of this process was conducted on two surrogate and seven actual tank sludge samples, including washing the sludge and treating the wash water although supernates were not included. Without any treatment, both surrogates failed toxicity characteristic TCLP limits for mercury, chromium, and lead. Using the 'Optimum' treatment provided by FWENC, both rinsed tank sludge surrogates were stabilized and passed TCLP characteristic limits. The wash/rinse from a simple surrogate of reagent grade chemicals and water passed TCLP after 'Optimum' treatment. However, the wash/rinse from a more representative surrogate gave mixed results; failing TCLP for mercury after both an 'Optimum' and an 'Alternate' treatment in the first triplicate set, but passing after either treatment in a repeat triplicate set. Both surrogates (sludge and wash/rinse) failed to pass Universal Treatment Standard (UTS) limits after both 'Optimum' and 'Alternate' treatments, implying that these treatments will not be satisfactory if the sludge is declared hazardous waste per RCRA.

The treatment results for the actual MVST sludge samples are summarized below:

1. Sludge samples taken from MVST W24, W25, W28 passed TCLP criteria after washing, but not those from W26, W27, and W31.

2. Sludge samples taken from MVST W26 and W27 failed the TCLP criterion for mercury after 'Optimum' FWENC treatment. The average and standard deviation of three TCLP extract mercury concentrations were $0.30 \pm 0.20$ and $0.52 \pm 0.22 \mathrm{mg} / \mathrm{L}$ for each tank, respectively.

3. Other critical RCRA metals in the MVST sludge samples were stabilized adequately in the 'Optimum' sludge treatment.

4. Examination of the mercury mass balances from the MVST tanks indicates that the FWENC rinsing process removes only a small portion of the sludge mercury (between 5 and 10\%) from the sludge samples. Characterization has shown that the samples taken from MVST tanks W26 and W27 contain substantially higher mercury levels than samples taken from other tanks. Subsequently, enough mercury extracts from these samples during TCLP testing to fail and the FWENC 'Optimum' treatment process failed to adequately stabilize the mercury enough to prevent TCLP failure.

5. The rinse cadmium concentration for the MVST W24 sludge sample exceeded the RCRA limit for wastewater. The sample was subjected to evaporation without stabilizer addition per the FWENC process. This test indicates that the FWENC trigger of when to add stabilizer failed to anticipate that evaporation alone was not sufficient to treat the sample from Tank W24 because enough cadmium washed out of the sludge to require stabilization.

6. Rinses from the MVST W25 sample failed for both cadmium and chromium. The sample was subjected to evaporation without stabilizer addition. This test also indicates that evaporation alone is not sufficient to treat waste samples, this time from Tank W25.

7. Rinses from MVST W26, W27, and W28 sludge samples exceeded the RCRA mercury concentration limit for wastewater. All three samples were subjected to the full 'Modified Optimum' process, with stabilizer addition. 
8. Mercury was partially stabilized and chromium was not stabilized for FWENC treated rinse water.

9. Durability tests with stabilized surrogate sludge samples, using freeze-thaw thermal cycling and long-term storage under ambient East Tennessee conditions, have indicated that the final waste form does not accumulate any substantial free water and continued to pass TCLP testing after a period of at least 9 months.

The key conclusions from this report follow:

1. Some dried liquid and some dried sludge samples were still hazardous by TCLP after treatment, indicating a significant risk of not meeting performance criteria for portions of the MVST sludge during a field treatment using the proposed process.

2. The TCLP failures for cadmium in the treated liquid, resulted from the process incorrectly predicting that no stabilizer addition was required. Modifying the calculation procedure may prevent future failures for a given sample, but these failures highlighted the risks involved in using grab samples to determine whether to add the stabilizer. Modest discrepancies in sample characterization made the difference between passing and failing.

3. Surrogate work indicated that lack of stabilizer was not a contributing cause to failure, so adding more stabilizer (as prescribed by the FWENC 'Alternate' process) will not result in a passing TCLP performance.

4. Surrogate work also indicated the treated waste will not accumulate free water or become hazardous as a result of being stored under local conditions. 


\section{REFERENCES}

Bayne, C. K., A. B. Walker and J. R. DeVore 1997. Statistical Description of Liquid Low-Level

Waste System Transuranic Wastes at Oak Ridge National Laboratory, Oak Ridge, Tennessee, ORNL/TM13351/ADDENDUM 1, Oak Ridge National Laboratory, Oak Ridge, Tenn.

Bayne, C. K., et al. 1993. Statistical Description of Liquid Low-Level Waste System Transuranic

Wastes at Oak Ridge National Laboratory, Oak Ridge, Tennessee, ORNL/TM-13351, Oak Ridge

National Laboratory, Oak Ridge, Tenn.

Gilliam, T. M. and R. D. Spence. 1999. Grout and Glass Performance in Support of Stabilization/Solidification of the MVST Tank Sludges. ORNL/TM-13652, Oak Ridge National Laboratory, Oak Ridge, Tenn.

Keller, J. M. and J. M. Giaquinto, 2001a. Characterization of the ORNL MVST Waste Tanks After Transfer of Sludge from BVEST, GAAT, and OHF Tanks, ORNL/TM-2000/323, Oak Ridge National Laboratory, Oak Ridge, Tenn.

Keller, J. M. and J. M. Giaquinto, 2001b. Characterization of the Radioactive Sludge from the ORNL MVST Waste Tanks, ORNL/TM-2001/151, Oak Ridge National Laboratory, Oak Ridge, Tenn.

Spence, R.D., et al. 1999. Grout and Glass Performance in Support of Stablization/Solidification of ORNL Tank Sludges, ORNL/TM-13712, Oak Ridge National Laboratory, Oak Ridge, Tenn. 
ORNL/TM-2003/30

\section{INTERNAL DISTRIBUTION}

1. J. W. Barton

2. B. H. Davison

3. J. M. Giaquinto

4. J. M. Keller

5. K. T. Klasson

6. B. E. Lewis

7. C. H. Mattus

8. J. W. Moore

9. S. M. Robinson

10. C. B. Scott
11-20. R. D. Spence

12. P. A. Taylor

13. A. B. Walker

14. J. F. Walker, Jr.

15. Central Research Library

16. ORNL Laboratory

Records-RC

17. ORNL Laboratory RecordsOSTI

\section{EXTERNAL DISTRIBUTION}

18. Dave E. Eaton, INEEL, MS 3875, Idaho Falls, ID 83415

19. E. W. (Bill) Holtzscheiter, Westinghouse Savannah River Company, Inc., Savannah River Technology Center, Building 773-A, Aiken, SC 29802

20. Christine A. Langton, Westinghouse Savannah River Company, Inc., Savannah River Technology Center, Building 773-43A, Aiken, SC 29802

21. Jacquie R. Noble-Dial, DOE Oak Ridge Operations Office, 55 Jefferson Building, Oak Ridge, TN 37831 